\title{
ORNL/M-3733
}

\section{Advanced Neutron Source Materials Surveillance Program}

\author{
Susan M. Heavilin \\ Purdue University
}

\section{MASTER}

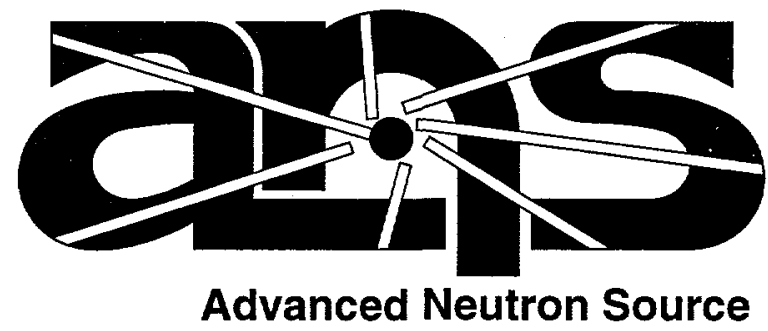

MANAGED BY

MARTIN MARIETTA ENERGY SYSTEMS, NNC.

FOR THE UNITEO STATES

DEPARTMENT OF ENERGY 
This report has been reproduced directly from the best available copy.

Available to DOE and DOE contractors from the Office of Scientific and Technical Information, P.O. Box 62, Oak Ridge, TN 37831; prices available from (615) 576-8401, FTS 626-8401.

Available to the public from the National Technical Information Service, U.S. Department of Commerce, 5285 Port Royal Rd., Springfield, VA 22161.

This report was prepared as an account of work sponsored by an agency of the United States Government. Neither the United States Government nor any agency thereof, nor any of their employees, makes any warranty, express or implied, or assumes any legal liability or responsibility for the accuracy, completeness, or usefulness of any information, apparatus, product, or process disclosed, or represents that its use would not infringe privately owned rights. Reference herein to any specific commercial product, process, or service by trade name, trademark, manufacturer, or otherwise, does not necesserily constitute or imply its endorsement, recommendation, or favoring by the United States Government or any agency thereof. The views and opinions of authors expressed herein do not necessarily state or reflect those of the United States Government or any agency thereof. 


\section{DISCLAIMER}

Portions of this document may be illegible in electronic image products. Images are produced from the best available original document. 


\title{
ADVANCED NEUTRON SOURCE \\ MATERIALS SURVEILLANCE PROGRAM
}

\author{
Susan M. Heavilin
}

Purdue University

August 1994

Date published: January 1995

\section{MASTER}

Prepared by

OAK RIDGE NATIONAL LABORATORY

Oak Ridge, Tennessee 37831-6285

managed by

MARTIN MARIETTA ENERGY SYSTEMS, INC.

for the

U.S. DEPARTMENT OF ENERGY

under Contract DE-AC05-84OR21400 


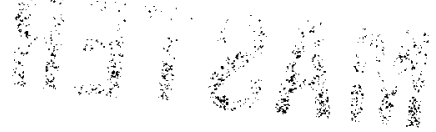




\section{CONTENTS}

Page

LIST OF FIGURES $\ldots \ldots \ldots \ldots \ldots \ldots \ldots \ldots \ldots \ldots \ldots \ldots$

LIST OF TABLES $\ldots \ldots \ldots \ldots \ldots \ldots \ldots \ldots \ldots \ldots \ldots \ldots \ldots$

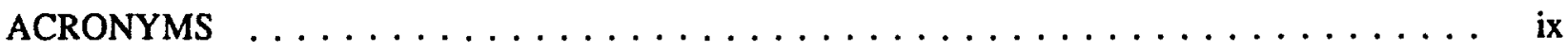

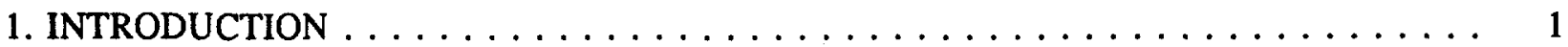

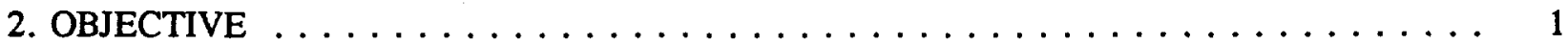

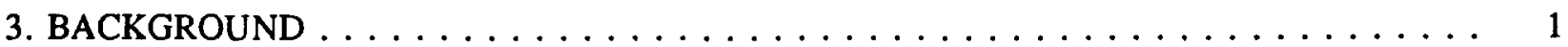

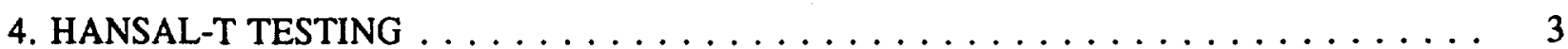

5. COMPACT vs SHORT ROD SPECIMENS $\ldots \ldots \ldots \ldots \ldots \ldots \ldots \ldots \ldots$

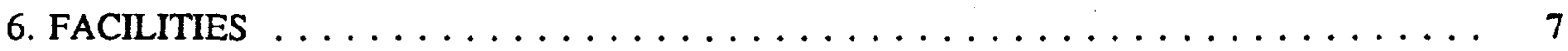

7. SUGGESTED FURTHER STUDY $\ldots \ldots \ldots \ldots \ldots \ldots \ldots \ldots \ldots \ldots$

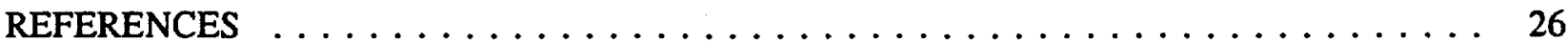

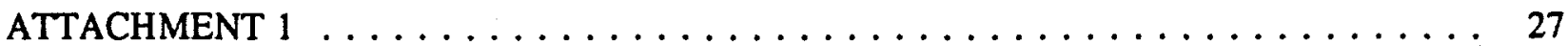





\section{FIGURES}

1. Section through the reactor assembly $\ldots \ldots \ldots \ldots \ldots \ldots \ldots \ldots \ldots$

2. Compact specimen $\mathrm{C}(\mathrm{T})$ standard proportions and tolerances $\ldots \ldots \ldots \ldots$

3. Schematic drawing of chevron-notched short rod specimen $\ldots \ldots \ldots \ldots$

4. Core pressure boundary tube short rod and tensile surveillance specimens-

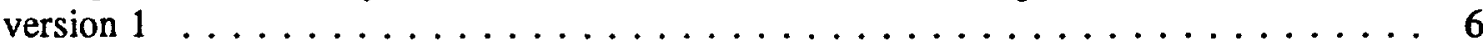

5. Core pressure boundary tube short rod and tensile surveillance specimens-

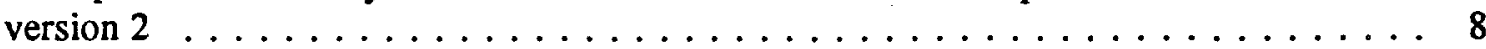

6. Core pressure boundary tube short rod and tensile surveillance specimens-

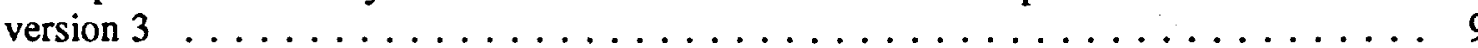

7. Core pressure boundary tube short rod and tensile surveillance specimens-

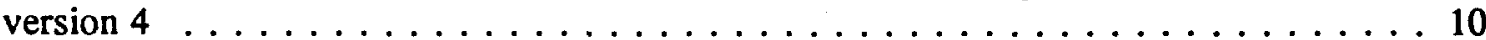

8. Core pressure boundary tube short rod and tensile surveillance specimens-

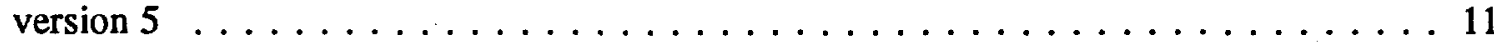

9. Core pressure boundary tube short rod and tensile surveillance specimens-

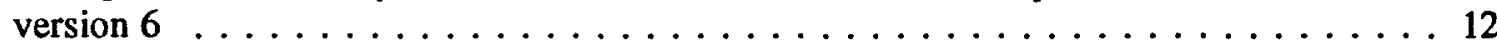

10. Core pressure boundary tube short rod and tensile surveillance specimens-

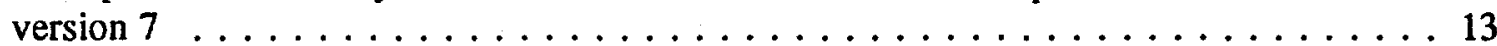

11. Core pressure boundary tube compact and tensile surveillance specimens . . . . . . . 14

12. Core pressure boundary tube base metal surveillance specimens-final version $\ldots \ldots \ldots 15$

13. Irradiation facilities in the Advanced Neutron Source reactor $\ldots \ldots \ldots \ldots$

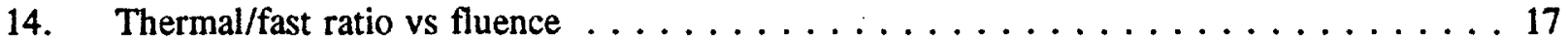

15. Core pressure boundary tube weld metal surveillance specimens-

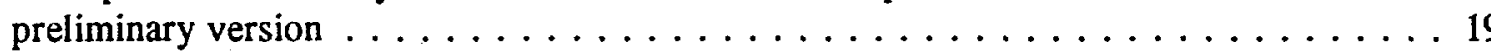

16. Reflector vessel facility for base, weld, and heat-affected-zone metals-

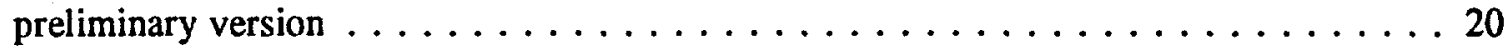

17. Reflector vessel facility for base or weld metals-preliminary version . . . . . . . . 21 
18. Reflector vessel facility for heat-affected-zone metals-preliminary version . . . . . 22

19. Core pressure boundary tube base metal short rod specimens $\ldots \ldots \ldots \ldots$

20. Core pressure boundary tube base metal short rod and tensile specimens . . . . . . . 24 


\section{TABLES}

$\underline{\text { Page }}$

1. Compact width vs short rod diameter calculations $\ldots \ldots \ldots \ldots$

2. Core pressure boundary tube and reflector vessel surveillance summary $\ldots \ldots \ldots 25$ 



\section{ACRONYMS}

ANS

ASME

ASTM

CPBT

HAZ

HFIR

INEL

Advanced Neutron Source

American Society of Mechanical Engineers

American Society for Testing and Materials

core pressure boundary tube

heat affected zone

High Flux Isotope Reactor

Idaho National Engineering Laboratory 


\section{INTRODUCTION}

The Advanced Neutron Source (ANS) will be composed of several different materials, one of which is 6061-T6 aluminum. Among other components, the reflector vessel and the core pressure boundary tube (CPBT), seen in Fig. 1, are to be made of 6061-T6 aluminum. These components will be subjected to high thermal neutron fluences and will require a surveillance program to monitor the strength and fracture toughness of the 6061-T6 aluminum over their lifetimes.

\section{OBJECTIVE}

The purpose of this paper is to explain the steps that were taken in the summer of 1994 toward developing the surveillance program. The first goal was to decide upon standard specimens to use in the fracture toughness and tensile testing. Second, facilities had to be chosen for specimens representing the CPBT and the reflector vessel base, weld, and heat-affected-zone (HAZ) metals. Third, a timetable had to be defined to determine when to remove the specimens for testing.

\section{BACKGROUND}

Neutron irradiation is known to cause embrittlement and loss of ductility in 6061-T6 aluminum. Therefore, code case $\mathrm{N}-519^{1}$ (Attachment 1) requires that a surveillance program be developed to allow use of this material in welded pressure vessels. The guideline for this surveillance program is the procedure for surveillance of light-water cooled reactor vessels, which is given in the American Society for Testing and Materials (ASTM) Std. E185-82 ${ }^{2}$. This standard is defined for steel pressure vessels and will have to be modified appropriately because the ANS will be using an aluminum pressure vessel.

ASTM Std. E185-82 defines the minimum number of capsules (irradiation exposure sets) needed for the surveillance program by the predicted transition temperature shift that the reactor vessel will undergo. The transition temperature shift is the difference in the index temperatures from the average Charpy curves measured before and after irradiation. ${ }^{2}$ Three different sets of specifications are given for the defined small, medium, and large temperature shifts. ${ }^{2}$ Note that unlike steels, aluminum does not exhibit a transition temperature. For the ANS surveillance program, it was decided to be on the safe side and follow the most stringent of these requirements as the guideline. In this case, the ASTM standard requires at least five surveillance capsules. Each of these capsules must contain $\mathbf{4 2}$ specimens. Of these specimens, 36 are to be Charpy impact specimens, and the remaining 6 are to be tensile specimens. Twelve Charpy specimens are required from base metal, weld metal, and HAZ metal, and three tensile specimens each from base and weld metal. Each capsule is to be removed after a predetermined amount of time and the specimens tested to see that the material is behaving as expected with respect to fracture toughness and tensile strength.

The ASTM standard defines the periods of time between removal of the capsules. These intervals correspond to $5 \%, 10 \%, 20 \%, 50 \%$, and $100 \%$ of the effective power years of the reactor. These same percentages will be used as a basis to determine the removal times of the specimens for the CPBT and the reflector vessel, based upon their respective expected lifetimes. However, the percentages cannot be followed exactly, since samples can be removed only when the reactor is shut down. These ASTM standard requirements will form the guideline for the ANS surveillance program, but they will be modified for the use of aluminum instead of steel for the pressure vessel. 


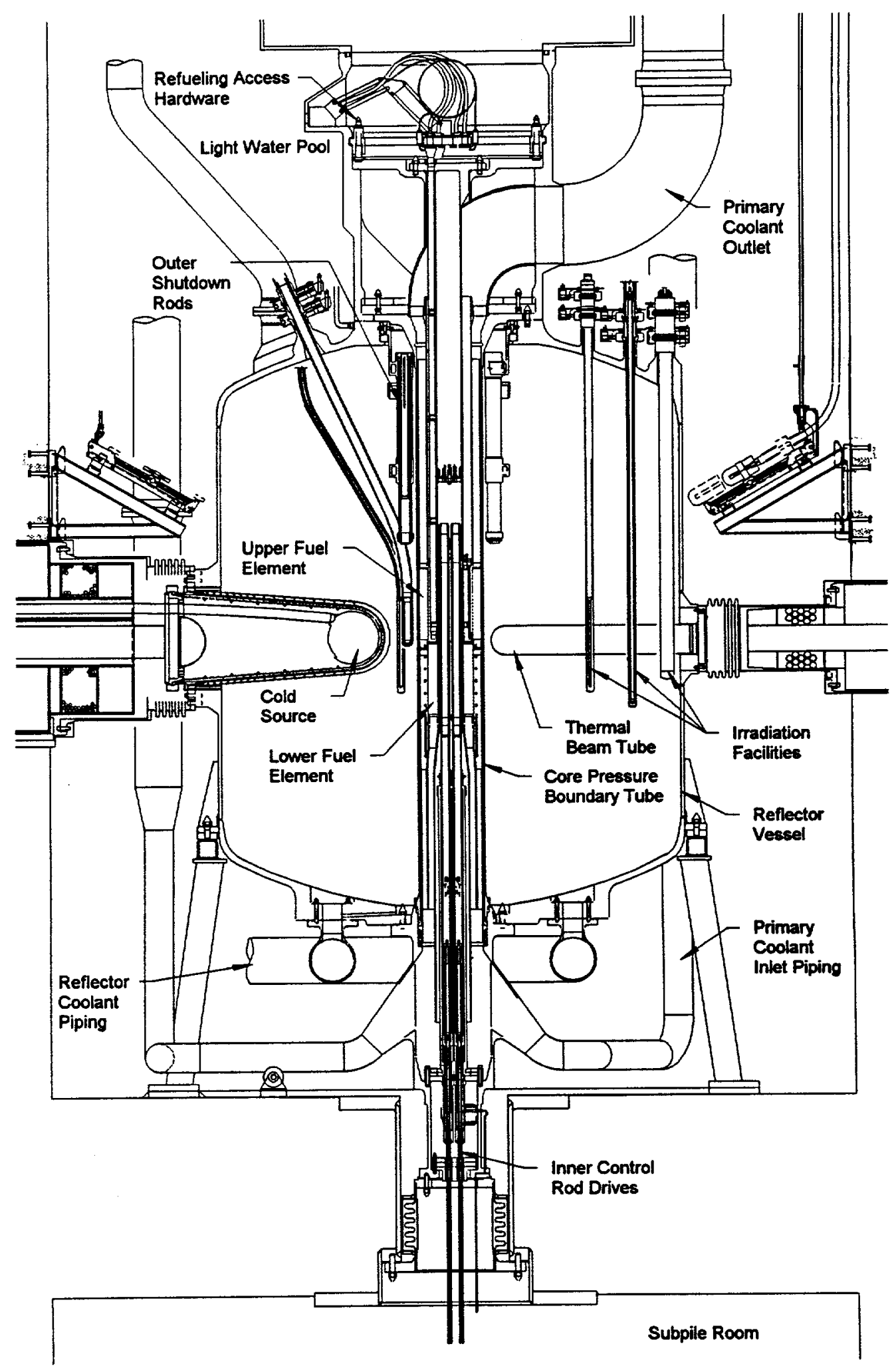

Fig. 1. Section through the reactor assembly. 


\section{HANSAL-T TESTING}

To assess the effects irradiation has on 6061-T6 aluminum, a testing program has been in place using capsules placed into the High Flux Isotope Reactor (HFIR) target positions. These HANSAL-T capsules have contained both tensile specimens and compact tension fracture toughness specimens. The first capsule, HANSAL-T1, ${ }^{3}$ was irradiated to a fluence of $1 \times 10^{26} \mathrm{~m}^{-2}(\mathrm{E}<0.625 \mathrm{eV})$. The second capsule, HANSAL-T2, ${ }^{4}$ was irradiated to a fluence of $8 \times 10^{26} \mathrm{~m}^{-2}(\mathrm{E}<0.625 \mathrm{eV})$. These capsules contained base metal 6061-T651 specimens.

The testing of the specimens in these two capsules has shown no large loss of fracture toughness, except at a test temperature of $150^{\circ} \mathrm{C}$, which is a higher temperature than is expected in the ANS. The yield and ultimate strengths of the material increased significantly with irradiation, as was expected. ${ }^{3,4}$ These are favorable results.

The HANSAL-T3 capsule, containing weld metal specimens, is currently scheduled to be removed from HFIR. It is being removed earlier than planned because it contains a screen similar to the one in HANSAL-T2 that was partially clogged upon removal. ${ }^{4}$ Removal of HANSAL-T3 at this early date is not a problem; it has already seen more fluence than the CPBT welds will be exposed to in their lifetime. ${ }^{5}$

\section{COMPACT vS SHORT ROD SPECIMENS}

The surveillance program for light-water cooled reactors in ASTM Std. E185-82 uses Charpy impact specimens to determine the shift in the nil-ductility temperature caused by reactor operation. Unlike the low-alloy steels, aluminum does not exhibit a nil-ductility temperature. The change in the plane-strain fracture toughness caused by reactor operation will be used to evaluate radiation damage. The plane-strain fracture toughness can then be used directly in analyses to determine when the vessel must be replaced to ensure that a non-ductility rupture will not occur.

The compact specimen used in the HANSAL-T capsules (Fig. 2) is used to evaluate plane-strain fracture toughness. However, there is an alternate fracture toughness specimen to this compact specimen. ASTM Std. E1304-896 outlines the use of a short rod specimen (Fig. 3) to measure the fracture toughness of metallic materials. This specimen has been used previously in the testing of 6061-T651 aluminum specimens ${ }^{7}$ and may be the best choice for the surveillance of the ANS.

ASTM fracture toughness standards require that the specimen size meet requirements that are based upon the ratio of the toughness to the yield strength squared $\left(\mathrm{K}_{\mathrm{Q}} / \sigma_{\mathrm{YS}}\right)^{2}$ (Table 1). ASTM Std. E399-90 $0^{8}$ requires that the width (B) of the fracture toughness specimen be two and a half times this ratio for aluminum alloys (Table 1). However if the short rod specimen is used, the width need only be one and a quarter times this ratio. ${ }^{6}$ The overall dimensions of the compact specimen required by E399-90 ${ }^{8}$ for the unirradiated material are $28 \times 67.2 \times 70 \mathrm{~mm}$, whereas the required dimensions of the short rod specimen are $14 \mathrm{~mm}$ diam. by $21 \mathrm{~mm}$ length. Therefore, the short rod specimen has one-fortieth of the volume of the compact specimen. Since there is little extra room in the ANS reflector vessel irradiation facilities, the short rod specimen seems to be a better choice than the compact specimen.

Typical values for $\mathrm{K}_{\mathrm{Q}}$ and $\sigma_{\mathrm{Ys}}$ (Table 1) were used to determine the minimum required value for the diameter of the short rod specimen. The height of the short rod specimen is defined as 1.6 times the diameter, including the loading flats. The minimum diameter for unirradiated 6061-T6 aluminum is $14.0 \mathrm{~mm}$ and the minimum diameter for highly irradiated $6061-\mathrm{T} 6$ aluminum was calculated to be $5.0 \mathrm{~mm}$. The first specimen size chosen was $20.0 \mathrm{~mm}$ in diameter and $32.0 \mathrm{~mm}$ in length (Fig. 4). 


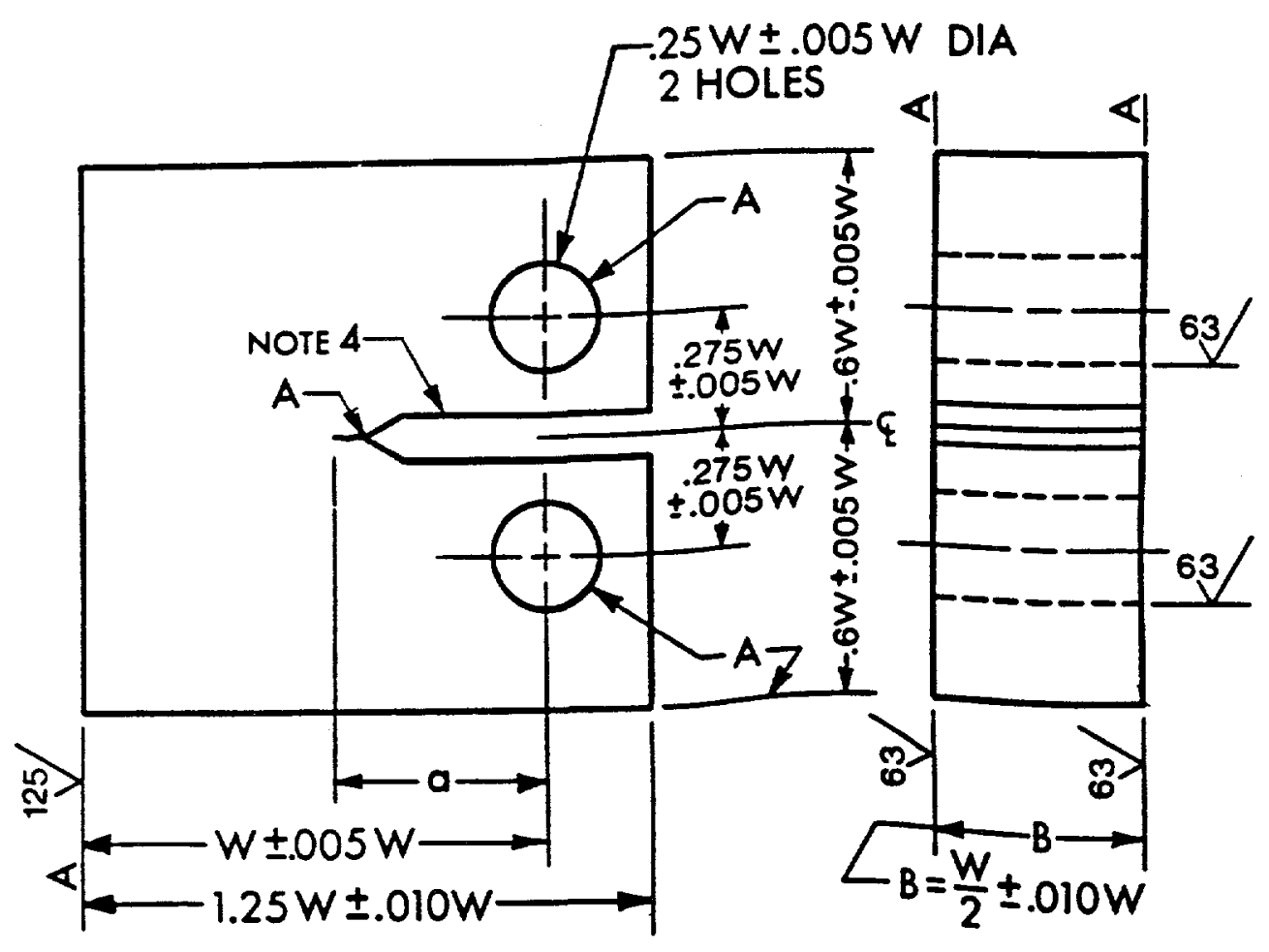

Fig. 2. Compact specimen $C(T)$ standard proportions and tolerances.

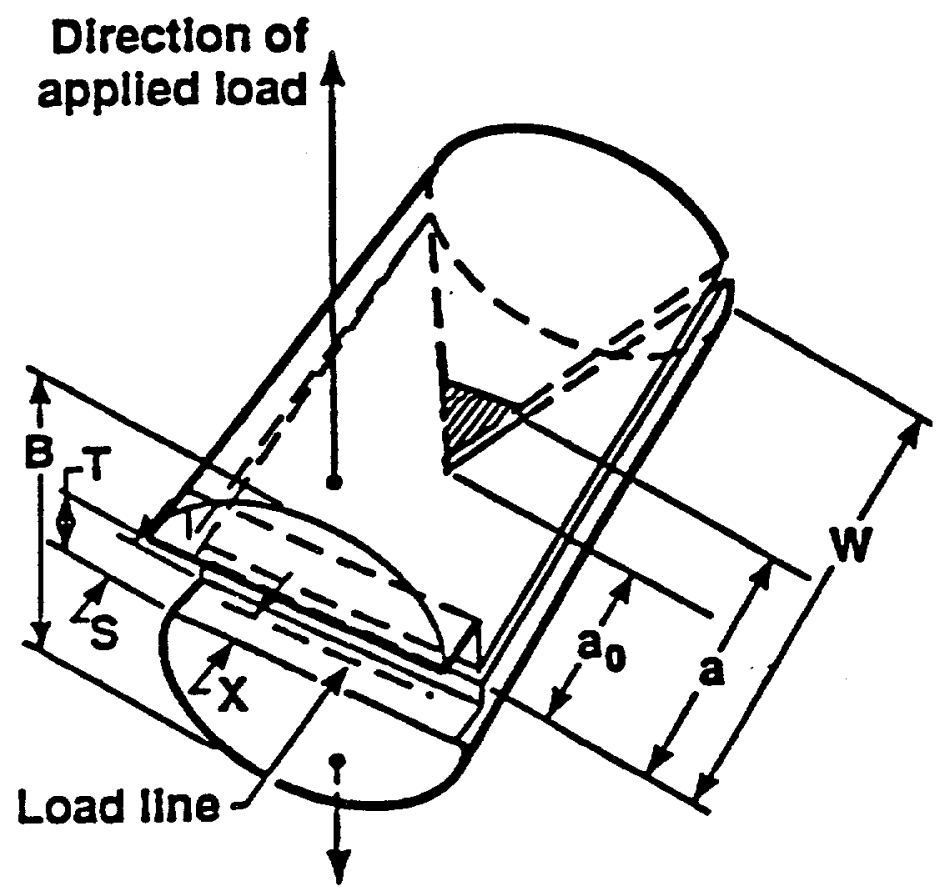

Fig. 3. Schematic drawing of chevron-notched short rod specimen. 


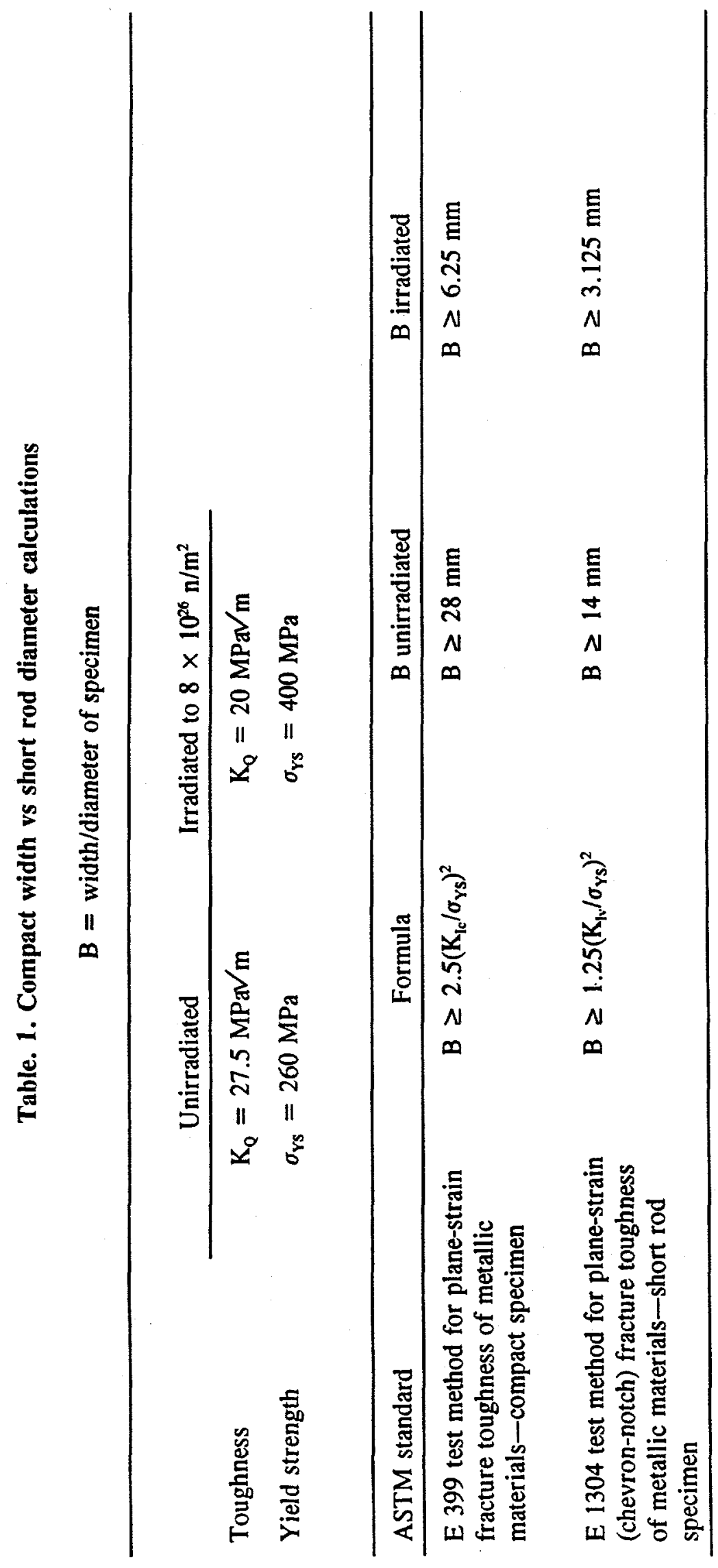




\section{Tensile Specimens - Slant Hole 1}

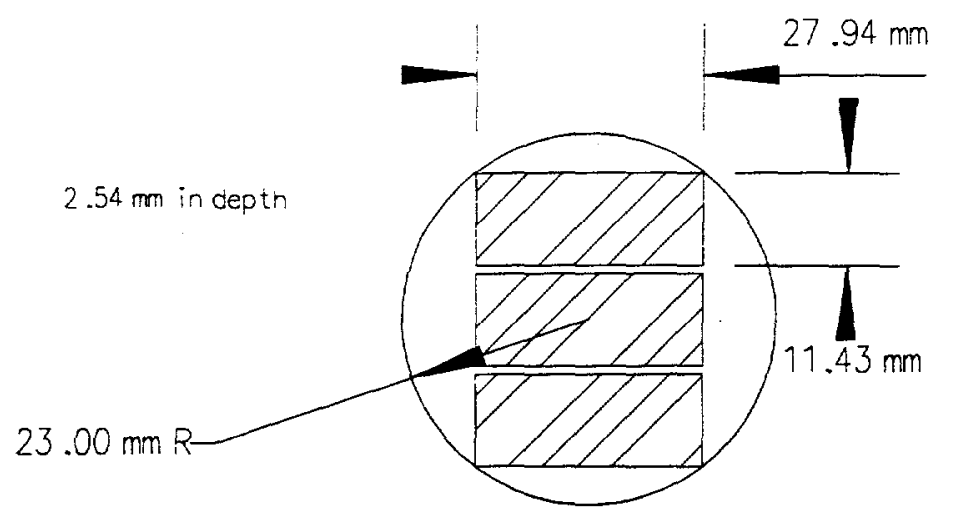

Fracture Toughness Specimens - Slant Hole 1

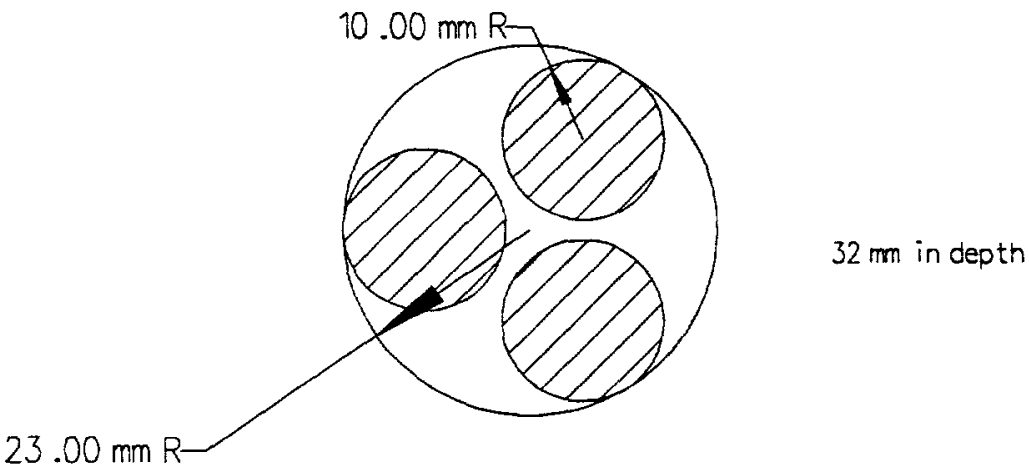

$$
\text { Slant Hole 1-Vertical View }
$$

Remove ofter:

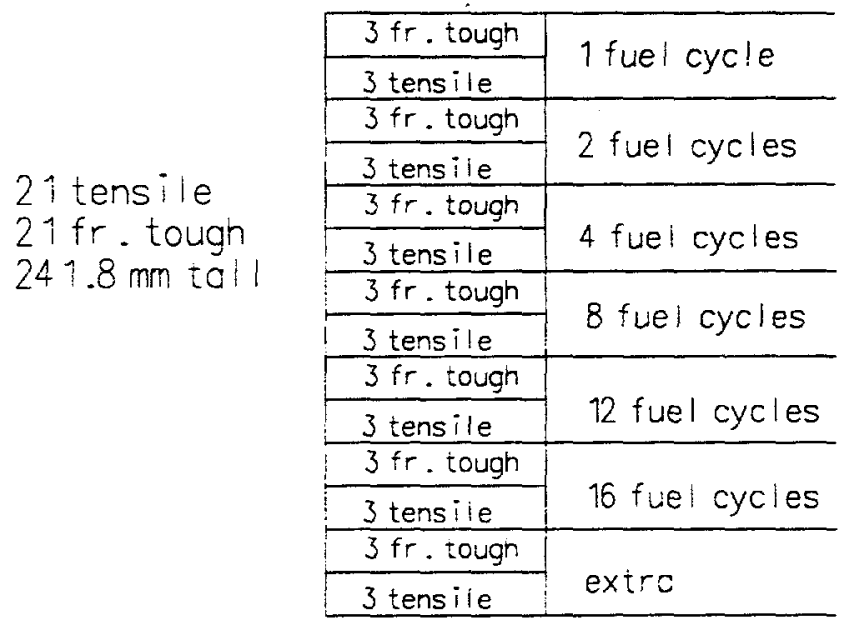

Fig. 4. Core pressure boundary tube short rod and tensile surveillance specimens-version 1. 
This was later changed to $12.0 \mathrm{~mm}$ in diameter and $19.2 \mathrm{~mm}$ in length to allow space for more specimens in the available facility (Figs. 5-10). See Sect. 6 for a discussion of this facility. The nine fracture toughness specimens included in Figs. 6-10 account for the CPBT base, weld, and HAZ metals, with three specimens from each of these metals.

The compact specimen used in the HANSAL-T experiments $(B=11.4 \mathrm{~mm})$ (Fig. 11) was then placed into the facility. Three specimens each are needed for the CPBT base, weld, and HAZ metals. One layer of tensile specimens is also needed. To have enough capsules to cover the 6-month lifetime of the CPBT and do the additional testing to see if it is possible to extend this lifetime, the overall facility would have to be $620 \mathrm{~mm}$ tall, compared with less than $300 \mathrm{~mm}$ for the short rod specimen (Fig. 10).

Finally, $16.0 \mathrm{~mm}$ was chosen as the standard specimen diameter to facilitate the testing process (Fig. 12), and this choice determined that the height of each specimen would be $25.6 \mathrm{~mm}$. It was then determined that these six specimens would be representative only of the CPBT base metal. The timetable decided upon (Fig. 12) corresponds approximately to $10 \%, 20 \%, 50 \%, 100 \%, 150 \%$, and $200 \%$ of the lifetime of the CPBT, which is similar to the guideline. ${ }^{2}$ Keeping six samples when only three are needed for the CPBT base metal will provide some extra specimens. It was decided to move the specimens for the CPBT weld and HAZ metals to locations that would better reflect their respective fluences and softer spectrums. These locations have not been determined yet, but the use of an existing isotope production facility looks promising.

\section{FACILITIES}

In addition to choosing a specimen size, it was also necessary to choose a facility in which to irradiate the specimens. The facility must have a flux similar to or higher than that of the component that it represents. In addition, the facility should be in a similar spectrum and be able to cool the specimens adequately. Because the 6-month lifetime of the CPBT is relatively short, it would be desirable to use an existing experimental facility to do the surveillance for the first year or two. Testing will be continued after the lifetime of the CPBT to see if it would be feasible to extend this lifetime. After this time, there will be no need to continue the surveillance, and the facility can be transferred to its original intended use. The reflector vessel, however, must be under surveillance for the lifetime of the reactor, so a new facility will have to be developed for its surveillance capsules.

After looking at the existing experimental facilities, the slant holes (Fig. 13) were chosen as possible facilities for the CPBT base metal samples. There are two slant hole experimental facilities, SH-1 and SH-2. The irradiation region for each is $46 \mathrm{~mm}$ in diameter and $300 \mathrm{~mm}$ tall. The thermalto-fast ratio in the slant holes corresponds relatively well to the expected thermal-to-fast ratio at the location of peak thermal fluence, so the samples should be representative of the irradiation that the CPBT is experiencing.

Figure 14 shows the thermal-to-fast ratio vs fluence from the top to the bottom of the CPBT after seven fuel cycles. The figure also shows the conditions at the location of the slant holes, as well as the conditions for the HANSAL-T testing. Two results for the slant holes are shown. One is the unperturbed value in the reflector vessel at the slant hole locations. The other is the Idaho Nuclear Engineering Laboratory (INEL) perturbed calculation with $13 \%$ stainless steel/87\% aluminum targets in place at the beginning of the cycle. For the anticipated life of seven fuel cycles, the peak thermal fluence on the CPBT is $5.1 \times 10^{26} \mathrm{n} / \mathrm{m}$ with a thermal-to-fast ratio of 7 . The slant hole with only aluminum specimens in it may a good match for the region of the CPBT with the highest fluence, because the fluence and spectrum should be somewhere between the slant hole unperturbed value and the perturbed value. However, these are preliminary figures. The CPBT data are taken from an INEL 
Fracture Toughness Spec imens - Slant Hole 1

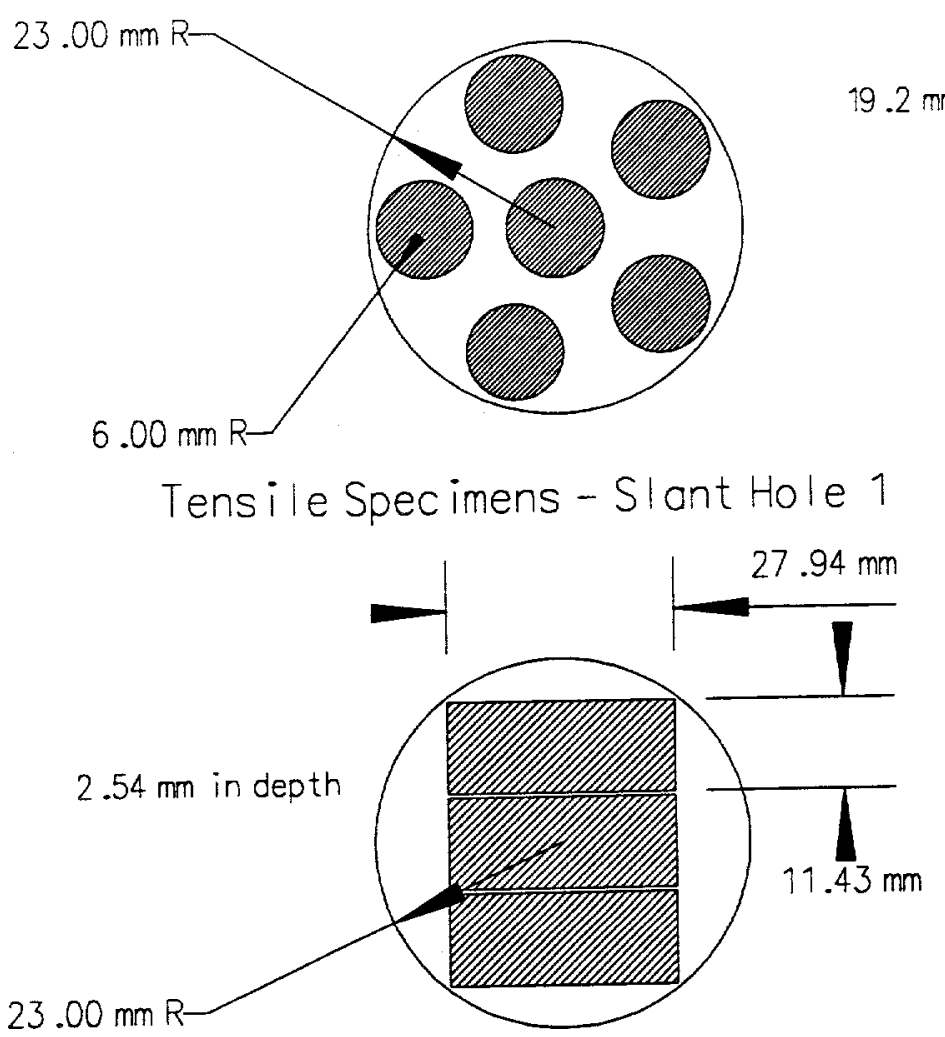

$$
\begin{aligned}
& \text { Slant Hole 1-Vertical View }
\end{aligned}
$$

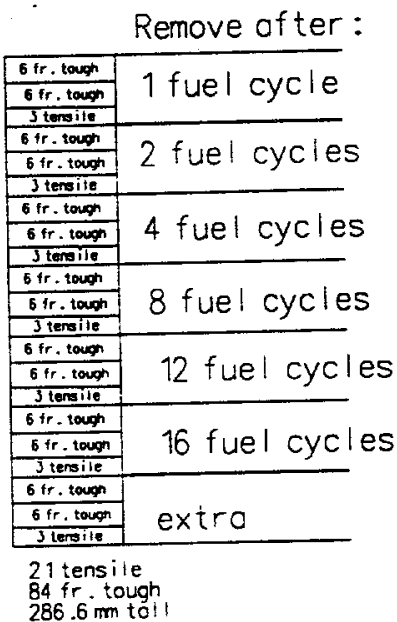

Fig. 5. Core pressure boundary tube short rod and tensile surveillance specimens-version 2. 


\section{Fracture Toughness Spec imens - SI ant Hole 1}

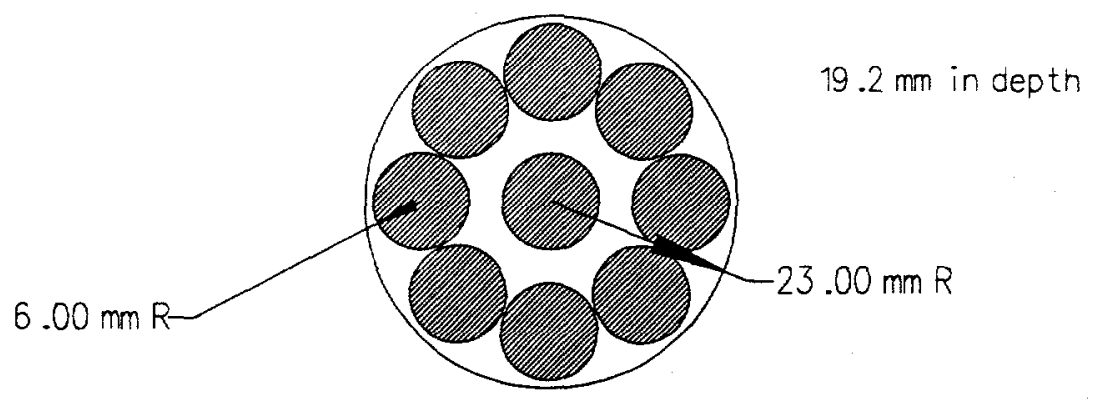

Tensile Specimens - Slant Hole 1

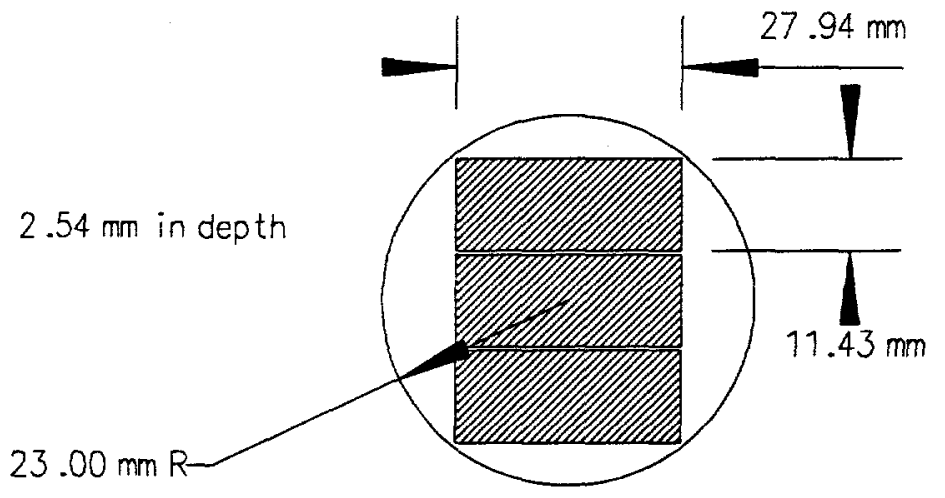

Slant Hole 1 -Vertical View

\begin{tabular}{|c|c|}
\hline & Remove ofter \\
\hline$\frac{9 \mathrm{fr} . \text { tough }}{3 \text { tensile }}$ & 1 fuel cycle \\
\hline$\frac{9 \mathrm{fr} \text {. tough }}{3 \text { tensile }}$ & 2 fuel cycles \\
\hline$\frac{9 \mathrm{fr} \text {. tough }}{3 \text { tensile }}$ & 4 fuel cycles \\
\hline$\frac{9 \mathrm{fr} \text {. tough }}{3 \text { tensile }}$ & 8 fuel cycles \\
\hline$\frac{9 \mathrm{fr} \text {. tough }}{3 \text { tensile }}$ & 12 fuel cycles \\
\hline$\frac{9 \mathrm{fr} \cdot \text { tough }}{3 \text { tensile }}$ & 16 fuel cycles \\
\hline$\frac{9 \mathrm{fr} \cdot \text { tough }}{3 \text { tensile }}$ & extro \\
\hline
\end{tabular}

21 tensile

$63 \mathrm{fr}$. tough

$152.2 \mathrm{~m}$ tall

Fig. 6. Core pressure boundary tube short rod and tensile surveillance specimens-version 3. 


\section{Tensile Specimens - Slant Hole 1}

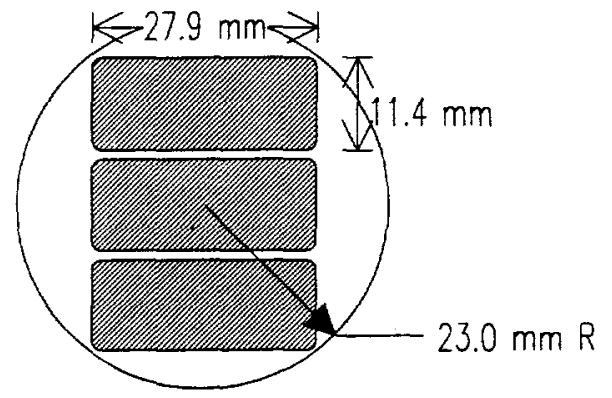

Fracture Toughness Specimens - Slant Hole 1

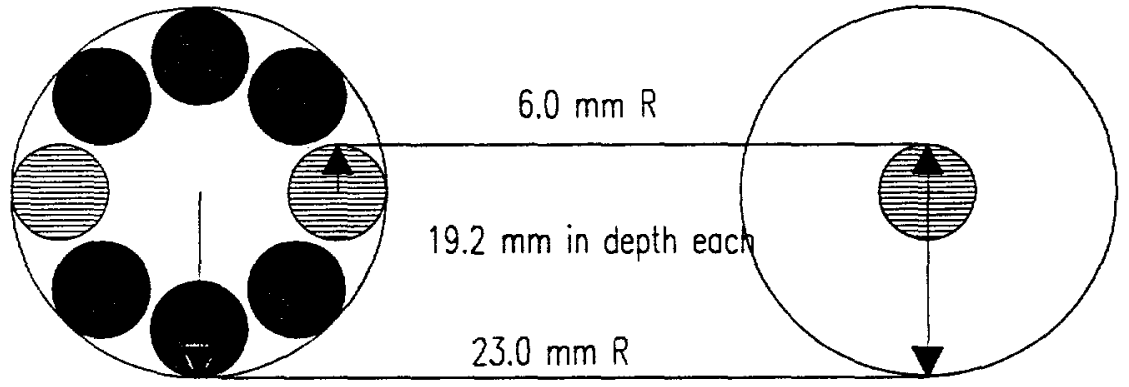

Slant Hole - Vertical View

\begin{tabular}{|c|c|c|}
\hline & 3 tensile & Remove ofter: \\
\hline & \begin{tabular}{|l|}
$8 \mathrm{fr}$ tough \\
$1 \mathrm{fr}$ tough \\
\end{tabular} & 1 fuel cycle \\
\hline & 3 tensile & \\
\hline $\begin{array}{l}21 \text { tensile } \\
63 \mathrm{fr} \text {. tough }\end{array}$ & $8 \mathrm{fr}$ tough & 2 fuel cycles \\
\hline $286.6 \mathrm{~mm}$ toll & 3 tensile & \\
\hline & \begin{tabular}{|l|l|}
$8 \mathrm{fr}$ tough \\
$1 \mathrm{fr}$ tough \\
\end{tabular} & 4 fuel cycles \\
\hline & \begin{tabular}{|c|}
3 tensile \\
8 fr tough \\
$1 \mathrm{fr}$ tough \\
\end{tabular} & 8 fuel cycles \\
\hline & \begin{tabular}{|c|}
3 tensile \\
8 fr tough \\
1 fr tough
\end{tabular} & 12 fuel cycles \\
\hline & \begin{tabular}{|c|}
3 tensile \\
$8 \mathrm{fr}$ tough \\
$1 \mathrm{fr}$ tough \\
\end{tabular} & 16 fuel cycles \\
\hline & \begin{tabular}{|c|}
3 tensile \\
$8 \mathrm{fr}$ tough \\
$1 \mathrm{fr}$ tough \\
\end{tabular} & extro \\
\hline
\end{tabular}

Fig. 7. Core pressure boundary tube short rod and tensile surveillance specimens-version 4. 


\section{Fracture Toughness Specimens - Slant Hole 1}

$19.2 \mathrm{~mm}$ in depth

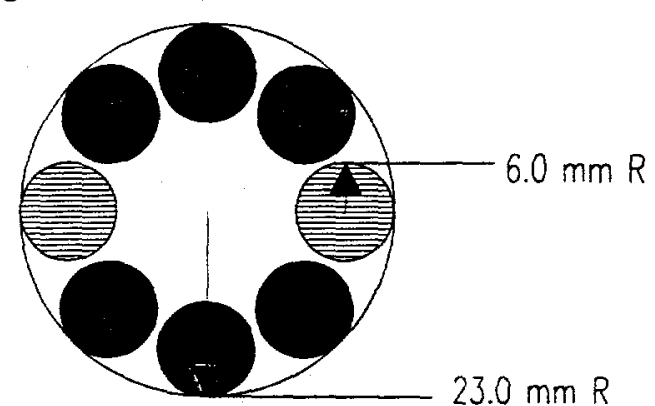

Fracture Toughness and Tensile Specimens - Slant Hole 1

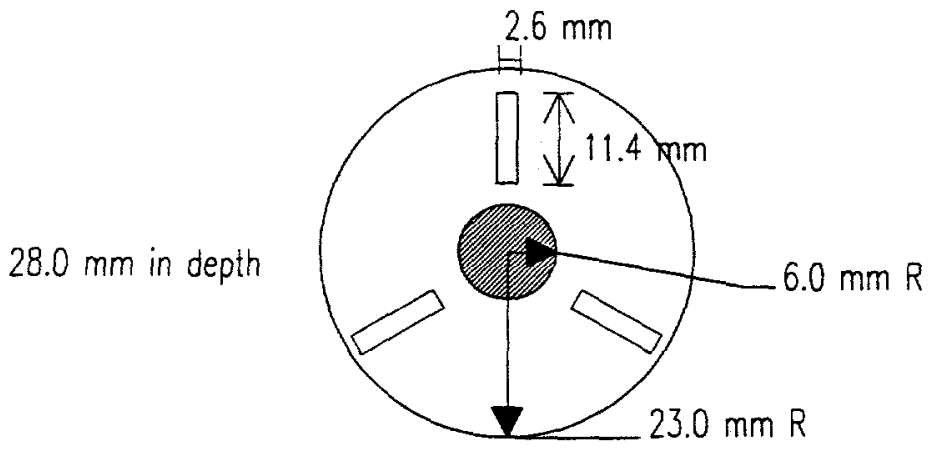

Slant Hole - Vertical View

\begin{tabular}{|c|c|}
\hline & \\
\hline$\frac{8 \mathrm{fr} \text { tough }}{3 \text { tensile \& } 1 \mathrm{fr} \text { lough }}$ & 1 fuel cycle \\
\hline 8 fr. tough & \multirow{2}{*}{2 fuel cycles } \\
\hline 3 tensile \& 1 fr tough & \\
\hline $8 \mathrm{fr}$. tough & \multirow{2}{*}{4 fuel cycles } \\
\hline 3 tensile \& I if tough & \\
\hline $8 \mathrm{fr}$ tough & \multirow{2}{*}{8 fuel cycles } \\
\hline 3 tensile \& $1 \mathrm{fr}$. tough & \\
\hline $8 \mathrm{fr}$ tough & \multirow{2}{*}{12 fuel cycles } \\
\hline 3 tensile \& 1 fr. tough & \\
\hline $8 \mathrm{fr}$ tough & \multirow[b]{2}{*}{16 fuel cycles } \\
\hline 3 tensile \& 1 fr tough & \\
\hline & \\
\hline 3 tensile \& $1 \mathrm{Hr}$. & \\
\hline
\end{tabular}

21 tensile

63 fr. tough

$330.4 \mathrm{~mm}$ toll

Fig. 8. Core pressure boundary tube short rod and tensile surveillance specimens-version 5. 


\section{Fracture Toughness Specimens - Slant Hole 1}

$19.2 \mathrm{~mm}$ in depth

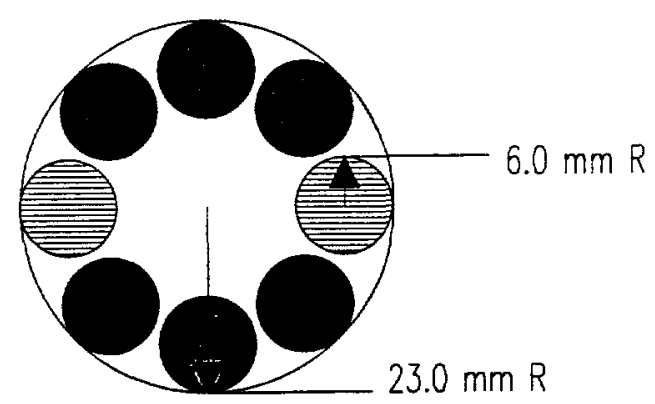

Tensile Specimens - Slant Hole 1

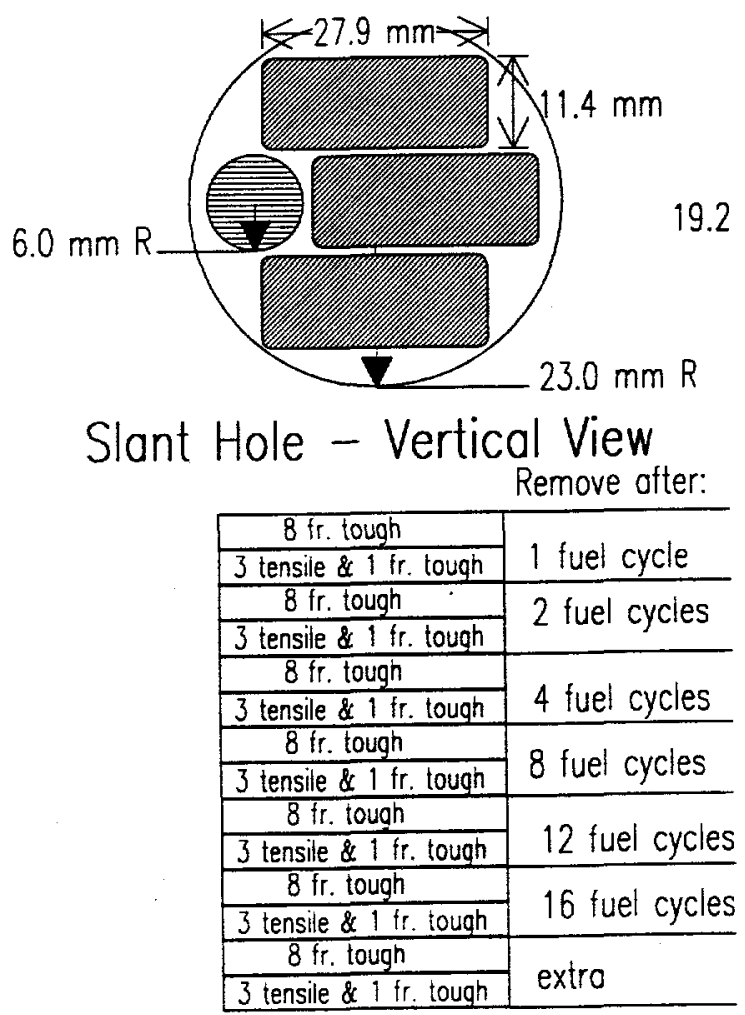

21 tensile

$63 \mathrm{fr}$. tough

$268.8 \mathrm{~mm}$ tall

Fig. 9. Core pressure boundary tube short rod and tensile surveillance specimens-version 6. 


\section{Fracture Toughness Specimens - Slant Hole 1}

$19.2 \mathrm{~mm}$ in depth

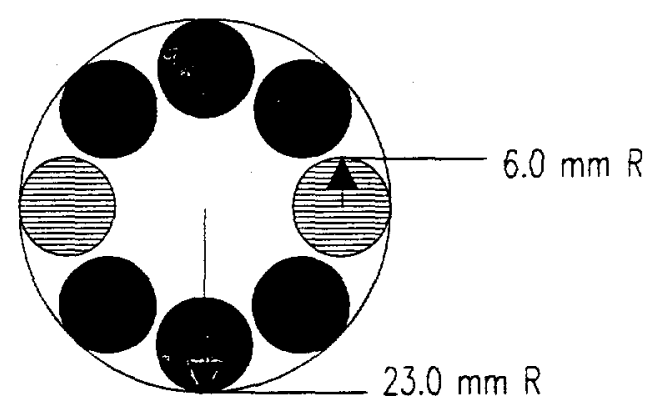

Tensile Specimens - Slant Hole 1

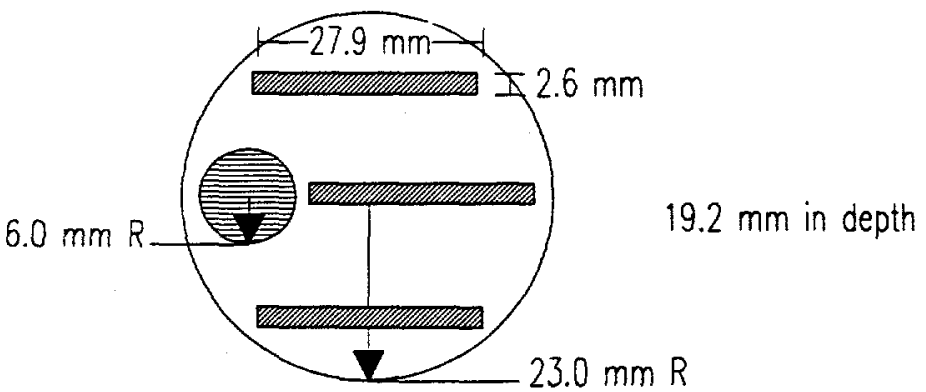

Slant Hole - Vertical View

\begin{tabular}{|c|c|}
\hline & \\
\hline 8 fr. tough & \multirow{2}{*}{1 fuel cycle } \\
\hline 3 tensile \& / fr. tough & \\
\hline $8 \mathrm{fr}$. tough & \multirow[b]{2}{*}{2 fuel cycles } \\
\hline 3 tensile \& I fr. tough & \\
\hline 8 fr. tough & \multirow{2}{*}{4 fuel cycles } \\
\hline 3 tensile \& 1 fr. tough & \\
\hline $8 \mathrm{fr}$. tough & \multirow{2}{*}{8 fuel cycles } \\
\hline 3 tensile \& 1 fr. tough & \\
\hline $8 \mathrm{fr}$. tough & \multirow{2}{*}{12 fuel cycles } \\
\hline 3 tensile \& 1 ir. tough & \\
\hline 8 fr. tough & \multirow{2}{*}{16 fuel cycies } \\
\hline 3 tensile \& 1 fr tough & \\
\hline $8 \mathrm{fr}$. tough & \multirow[b]{2}{*}{ extro } \\
\hline 3 tensile \& $1 \mathrm{fr} . \mathrm{t}$ & \\
\hline
\end{tabular}

21 tensile

$63 \mathrm{fr}$. tough

$268.8 \mathrm{~mm}$ tall

Fig. 10. Core pressure boundary tube short rod and tensile surveillance specimens-version 7. 

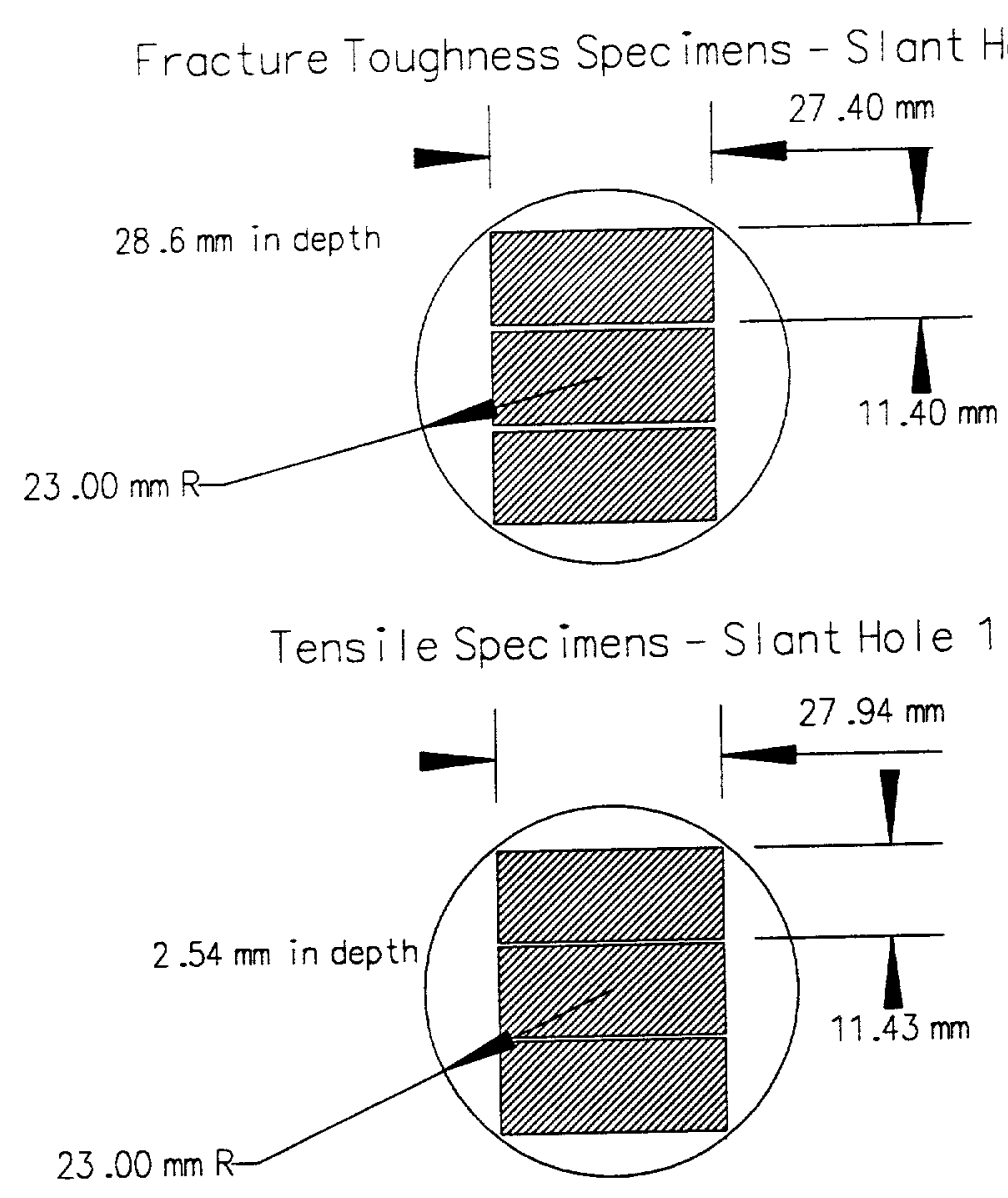

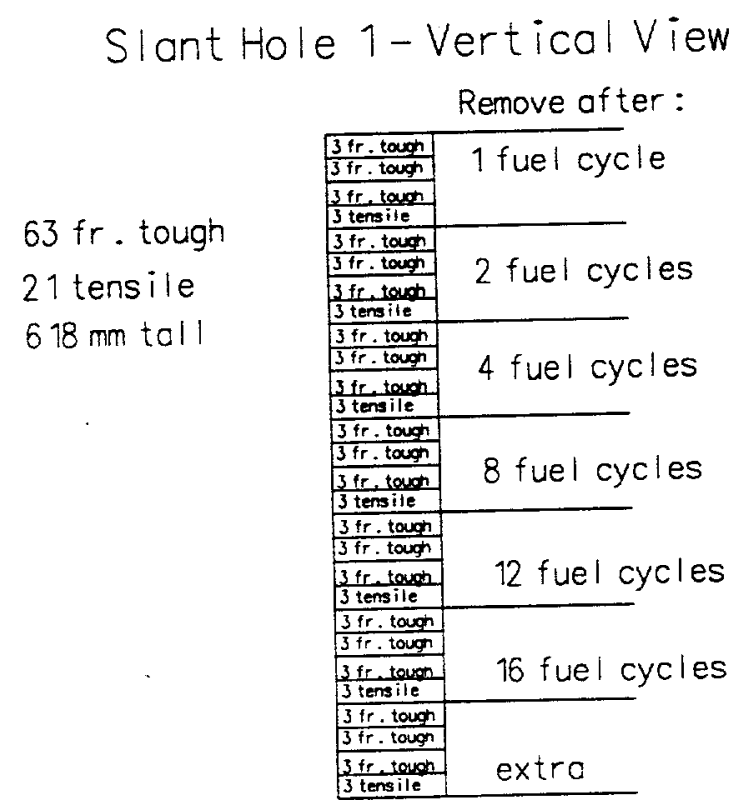

Fig. 11. Core pressure boundary tube compact and tensile surveillance specimens. 
Slant Hole 1 - Fracture Toughness Spec imens $23.0 \mathrm{~mm}$ R-

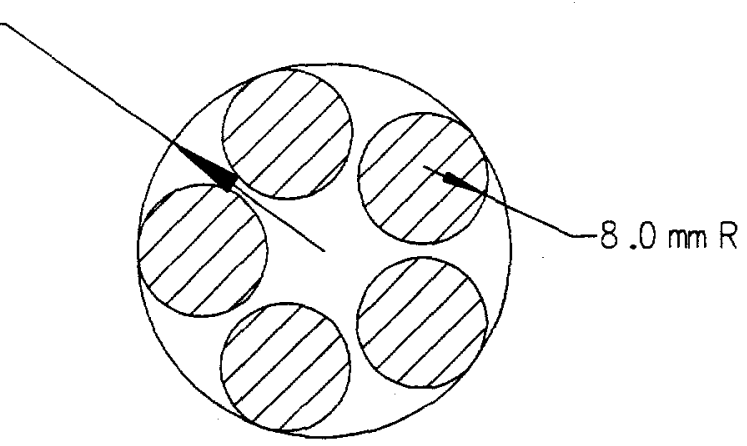

$25.6 \mathrm{~mm}$ in depth

Fracture Toughness and Tens ile Specimens

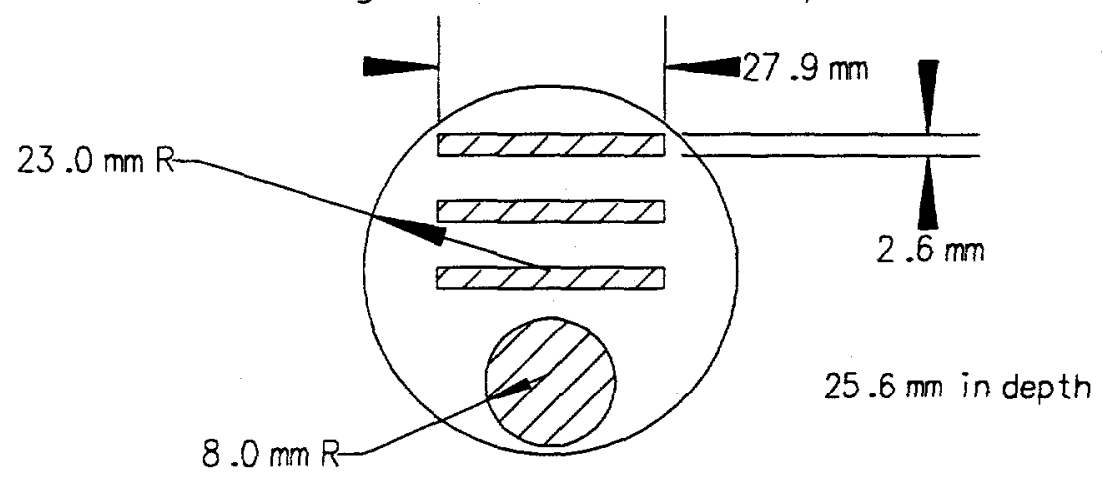

Slant Hole-Vertical View

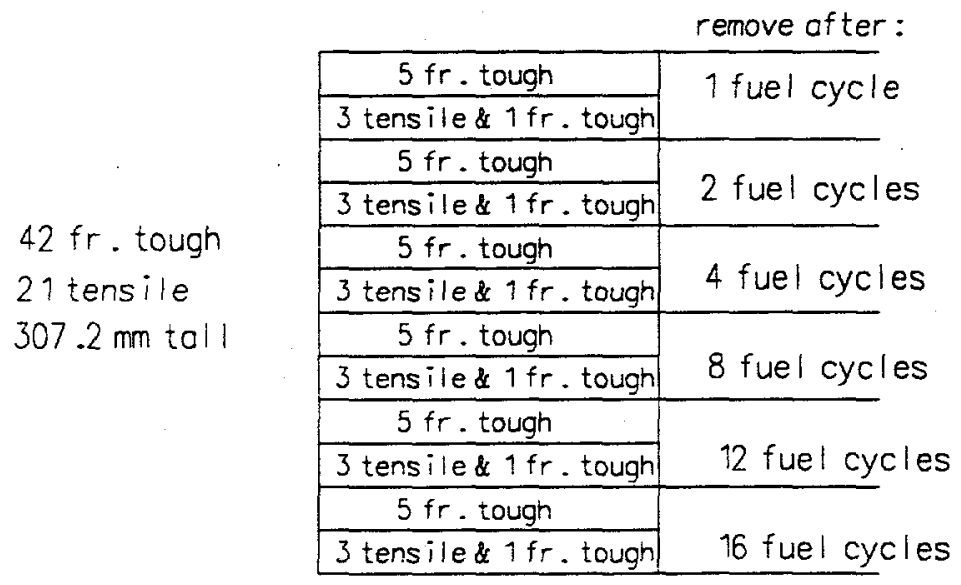

Fig. 12. Core pressure boundary tube base metal surveillance specimens-final version. 


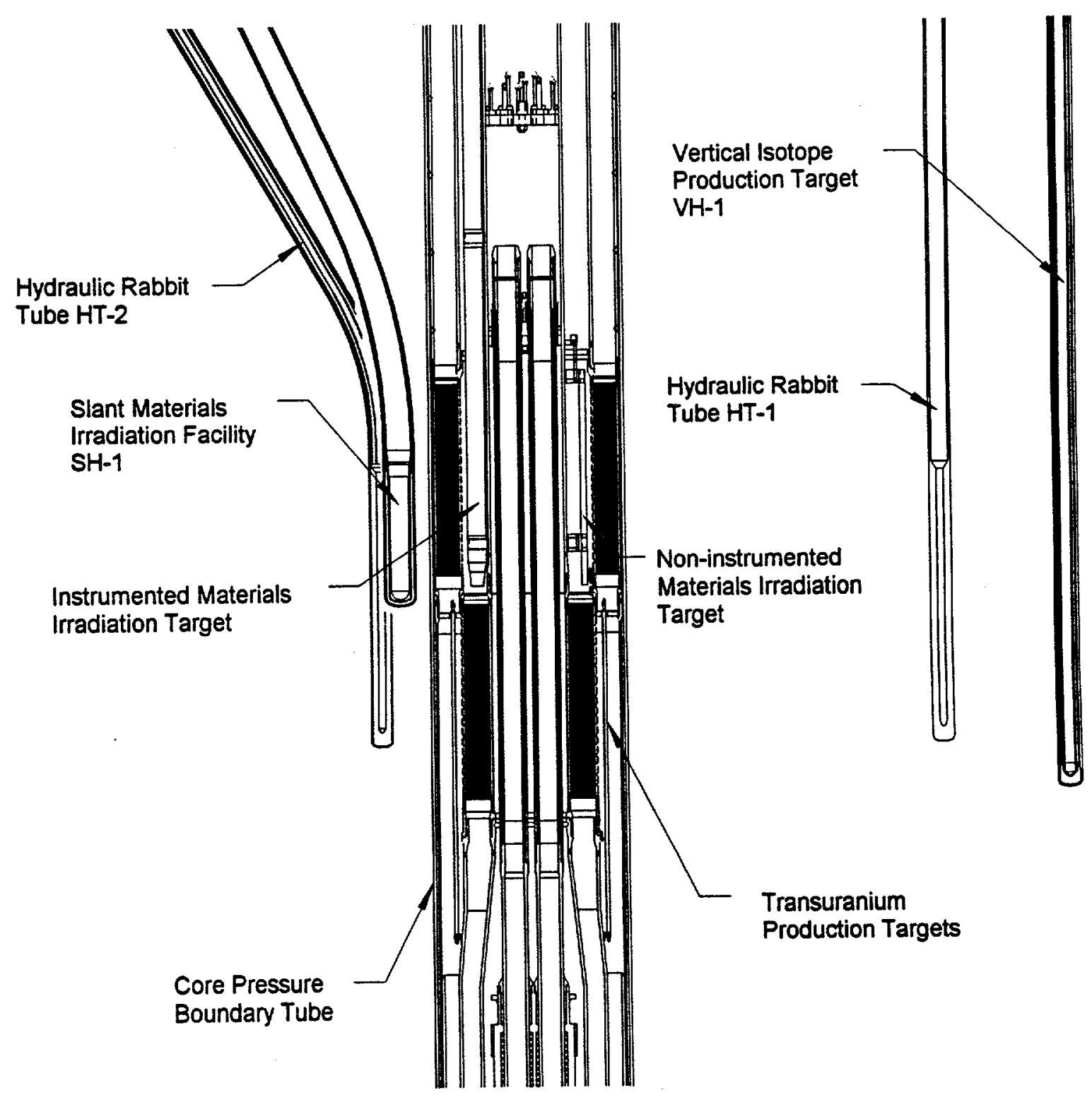

Fig. 13. Irradiation facilities in the Advanced Neutron Source reactor. 


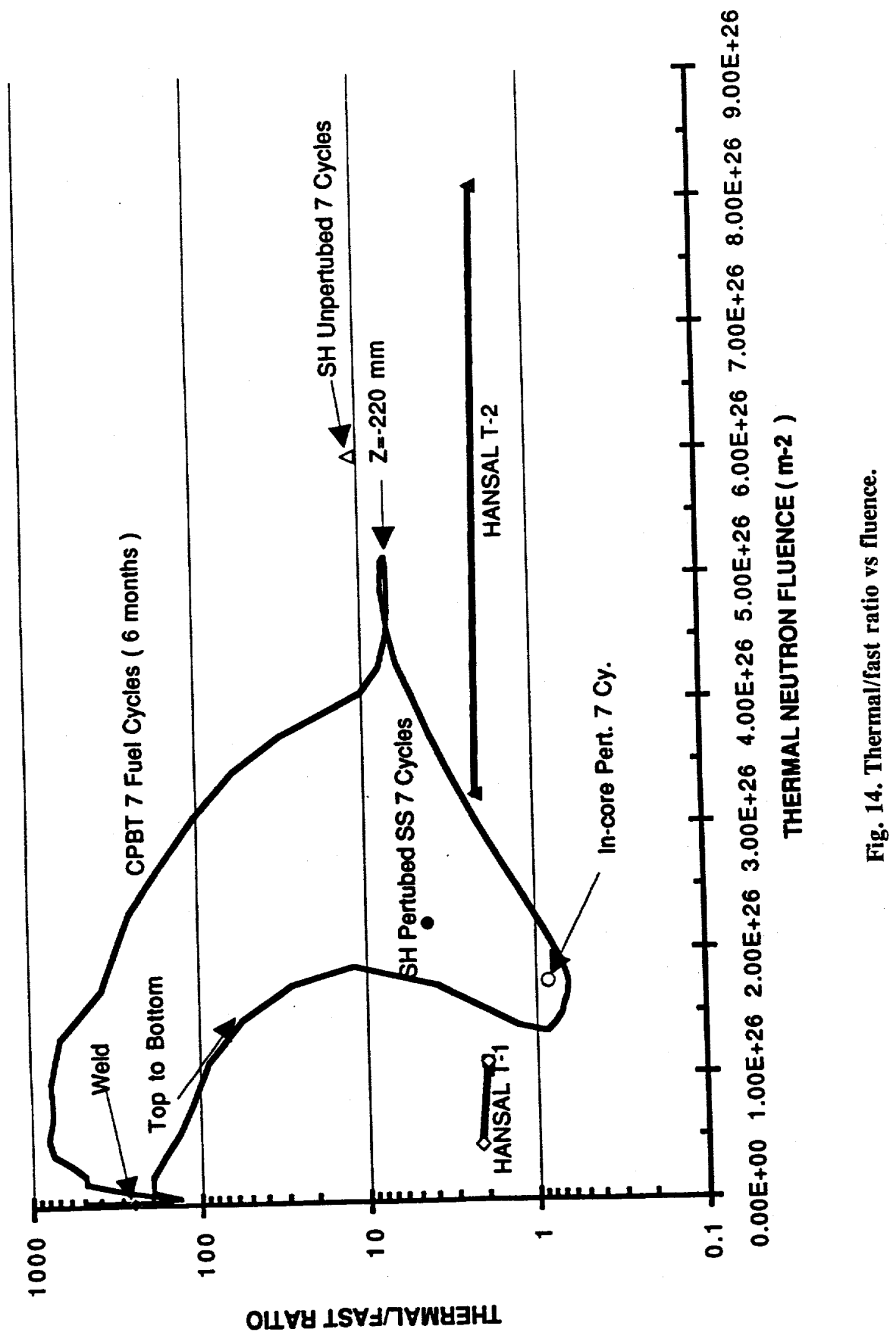


Monte Carlo calculation of the flux profile along the CPBT at beginning of cycle. ${ }^{9}$ The figure was drawn assuming that the flux remains constant for the duration of the fuel cycle, which is an approximation. In addition to having a similar thermal-to-fast ratio, the slant holes are cooled by a heavy-water flow of $10 \mathrm{~kg} / \mathrm{s}$ that uses a supply pressure of $1 \mathrm{MPa}$. It is believed that this flow will cool the surveillance specimens adequately.

After the sample size and the facility size were determined, the layout of the samples could be investigated. All of the necessary fracture toughness and tensile samples for the CPBT base metal will fit into one of the slant holes, leaving the other slant hole to perform its intended function. In contrast, if the HANSAL-T compact specimen had been chosen, there would not have been enough room in both of the slant hole facilities (Fig. 11) for all of the specimens.

The facilities for the CPBT weld and HAZ metals have not been determined yet. It is uncertain at this point whether there are adequate existing facilities, or if new facilities must be designed; use of an existing isotope production facility is a likely possibility, and one preliminary drawing has been done using a vertical hole as this facility (Fig. 15).

The facility for the reflector vessel surveillance samples will have to be a new facility because it will be used for the life of the reactor. The facility should be placed near the surface of the reflector vessel near the midplane. If possible, the specimen size will be kept the same. Some preliminary drawings have been done, giving different options for this facility (Figs. 16-18). This facility must be accessible so that the surveillance specimens can be removed for testing, and it must be capable of cooling the specimens adequately.

\section{SUGGESTED FURTHER STUDY}

Although the surveillance specimens and facilities have been determined for the CPBT base metal (Table 2), the facilities that will be used for the CPBT weld and HAZ metals must be finalized, as must the design of the reflector vessel facilities. In addition, there may be other components of the reactor that need to have surveillance programs, such as the core support system. These additional surveillance programs will have to be determined separately, but similarly to the CPBT program.

The baskets for holding the specimens inside the CPBT base metal capsules still must be completed. Three-dimensional drawings of the specimens placed in their initial baskets are included as Figs. 19 and 20.

In addition, tests should be performed on 6061-T6 aluminum samples to compare fracture toughness results using the short rod specimen with results using the compact fracture toughness specimen. These tests are needed to confirm that the short rod specimen will be able to monitor the fracture toughness of the 6061-T6 aluminum as well as the compact specimen can. 
Vertical Hole 1 - Fracture Toughness Specimens

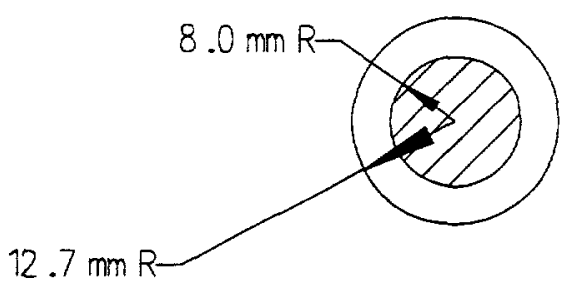

$$
25.6 \mathrm{~mm} \text { in depth }
$$

Vertical Hole 1 - Tens ile Specimens

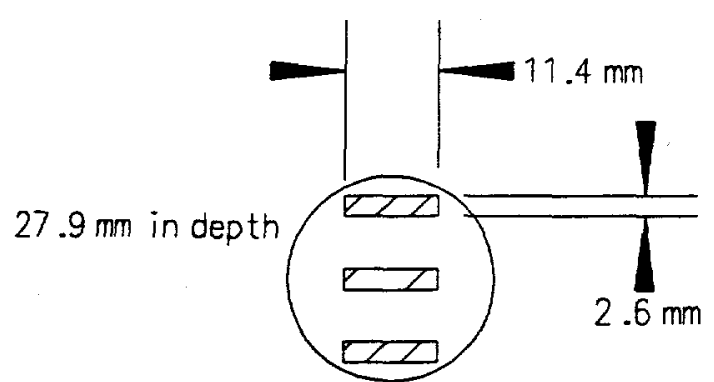

Vertical Hole 1 - Vertical View

Remove after:

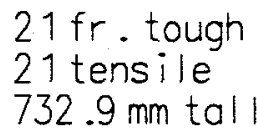

\begin{tabular}{|c|c|}
\hline $1 \mathrm{fr}$. tough & \multirow{4}{*}{1 fuel cycle } \\
\hline $1 \mathrm{fr}$. tough & \\
\hline $1 \mathrm{fr}$. tough & \\
\hline 3 tensile & \\
\hline $1 \mathrm{fr}$. tough & \multirow{4}{*}{2 fuel cycles } \\
\hline $1 \mathrm{fr}$. tough & \\
\hline ifr. tough & \\
\hline 3 tensile & \\
\hline $1 \mathrm{fr}$. tough & \multirow{4}{*}{4 fuel cycles } \\
\hline $1 \mathrm{fr}$. tough & \\
\hline$i \mathrm{fr}$. tough & \\
\hline 3 tensile & \\
\hline ifr. tough & \multirow{4}{*}{8 fuel cycles } \\
\hline $1 \mathrm{fr}$. tough & \\
\hline $1 \mathrm{fr}$. tough & \\
\hline 3 tensile & \\
\hline $1 \mathrm{fr}$. tough & \multirow{4}{*}{12 fuel cycles } \\
\hline Ifr. tough & \\
\hline $1 \mathrm{fr}$. tough & \\
\hline 3 tensile & \\
\hline $1 \mathrm{fr}$. tough & \multirow{4}{*}{16 fuel } \\
\hline $1 \mathrm{fr}$. tough & \\
\hline $1 \mathrm{fr}$. tough & \\
\hline 3 tensile & \\
\hline $1 \mathrm{fr}$. tougn & \multirow{4}{*}{ extra } \\
\hline $1 \mathrm{fr}$. tough & \\
\hline $1 \mathrm{fr}$. tough & \\
\hline 3 tensile & \\
\hline
\end{tabular}

Fig. 15. Core pressure boundary tube weld metal surveillance specimens-preliminary version. 


\section{Fracture Toughness Spec imens}

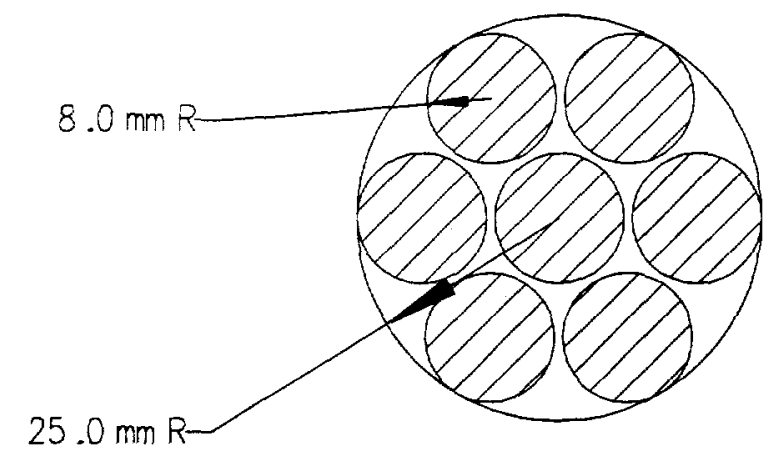

$25.6 \mathrm{~mm}$ in depth

Fracture Toughness and Tensile Spec imens

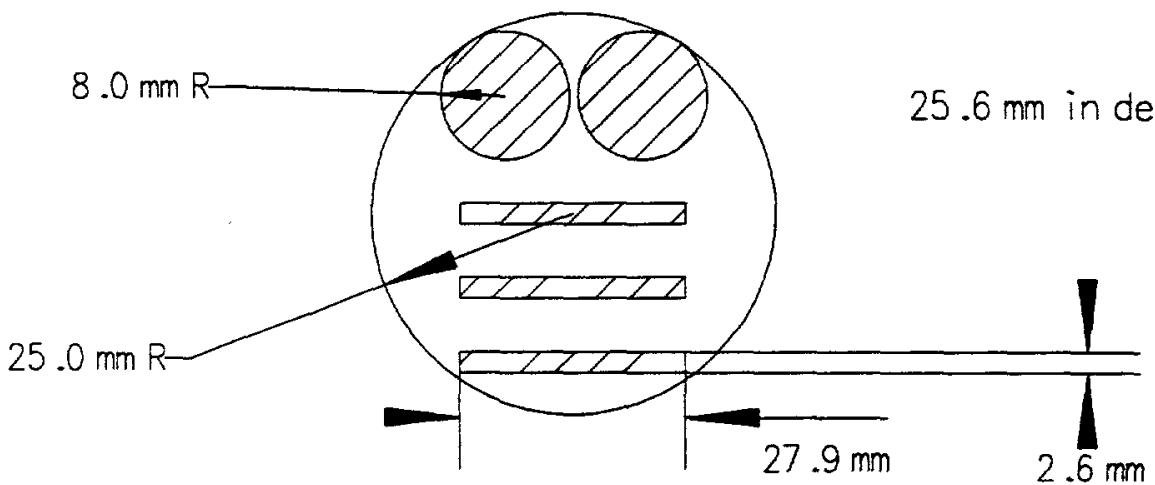

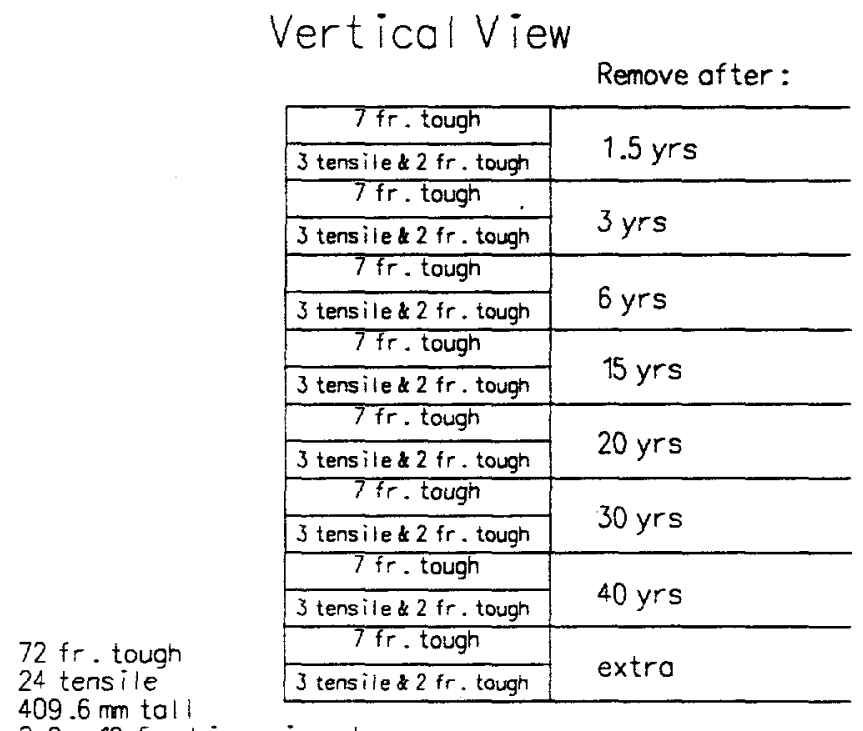

$8.0 \times 10-5$ cub ic $\mathrm{mm}$ in volume

Fig. 16. Reflector vessel facility for base, weld, and heat-affected-zone metalspreliminary version. 


\section{Fracture Toughness Specimens}

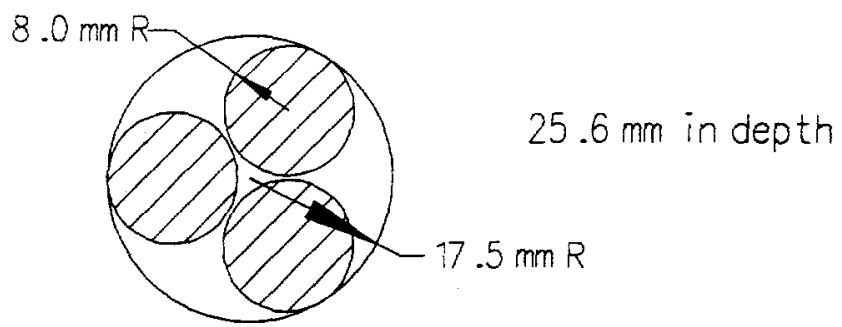

Tensile Specimens

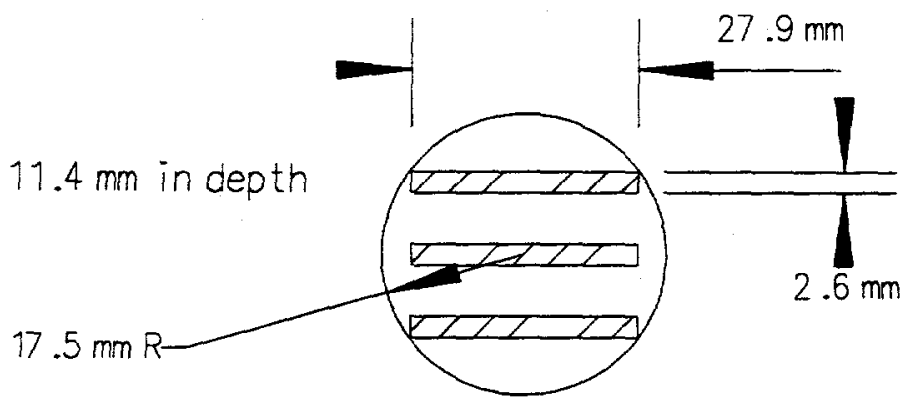

Vertical View

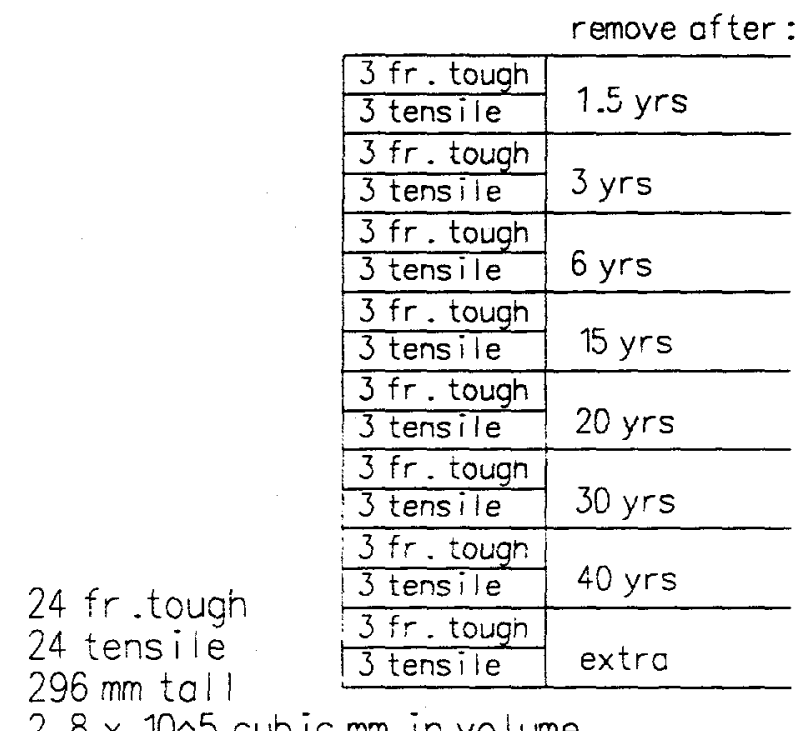

Fig. 17. Reflector vessel facility for base or weld metals-preliminary version. 
Fracture Toughness Spec imens

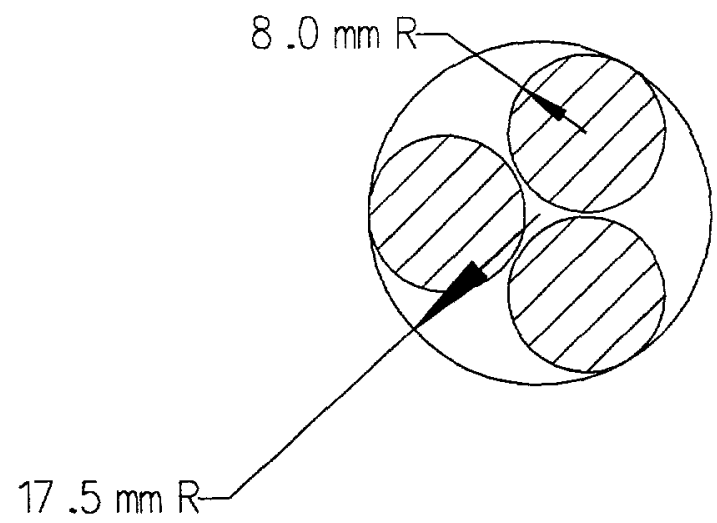

\title{
$25.6 \mathrm{~mm}$ in depth
}

\author{
Vertical View
}

remove after:

\begin{tabular}{|l|l}
\hline $3 \mathrm{fr}$. tough & $1.5 \mathrm{yrs}$ \\
\hline $3 \mathrm{fr}$. tough & $3 \mathrm{yrs}$ \\
\hline $3 \mathrm{fr}$. tough & $6 \mathrm{yrs}$ \\
\hline $3 \mathrm{fr}$. tough & $15 \mathrm{yrs}$ \\
\hline $3 \mathrm{fr}$. tough & $20 \mathrm{yrs}$ \\
\hline $3 \mathrm{fr}$. tough & $30 \mathrm{yrs}$ \\
\hline $3 \mathrm{fr}$. tough & $40 \mathrm{yrs}$ \\
\hline $3 \mathrm{fr}$. tough & extra \\
\hline
\end{tabular}

\author{
$24 \mathrm{fr}$. tough \\ $204.8 \mathrm{~mm}$ tall \\ $2.0 \times 10 \wedge 5$ cub ic mm in volume
}

Fig. 18. Reflector vessel facility for heat-affected-zone metals-preliminary version. 


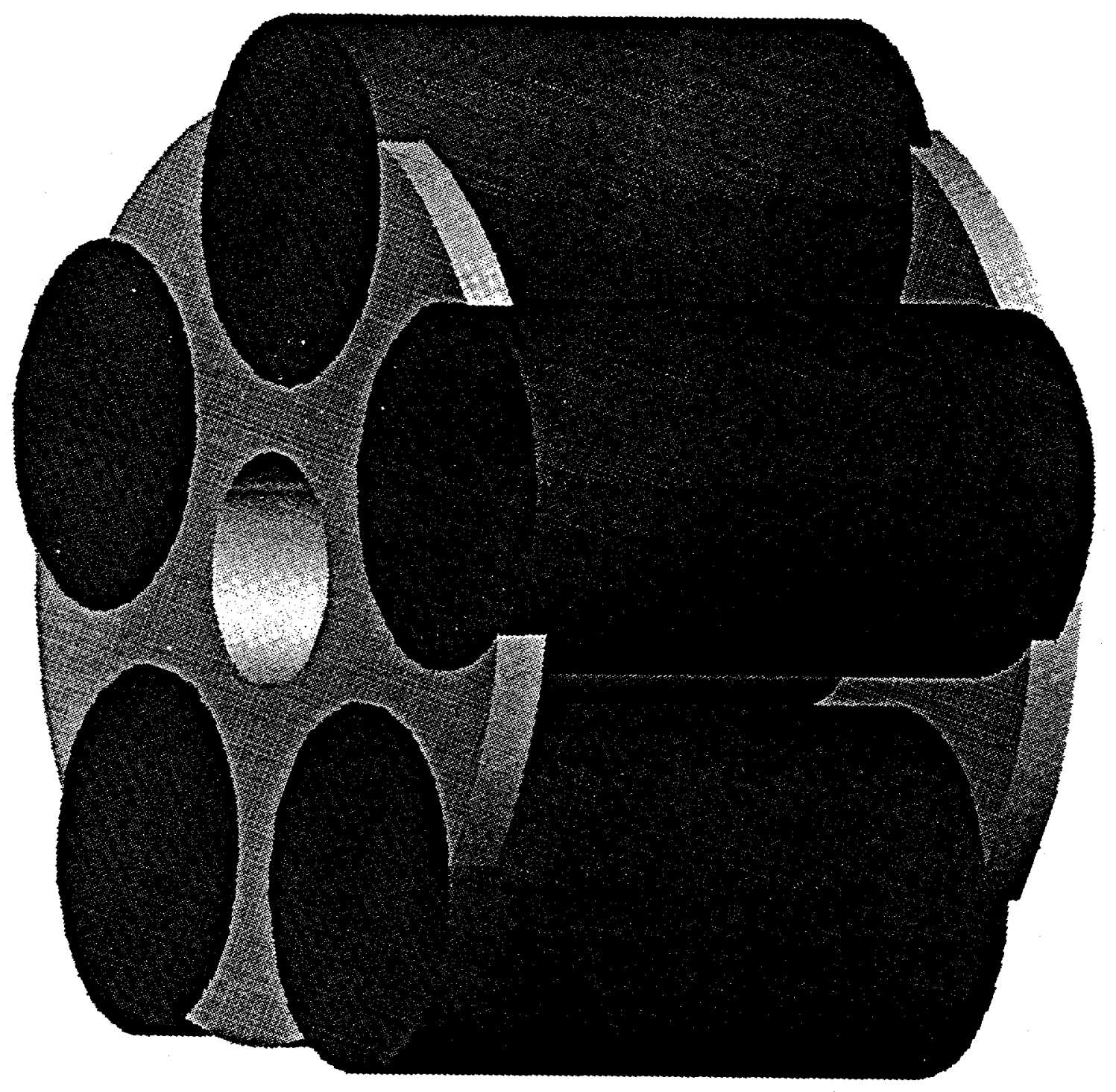

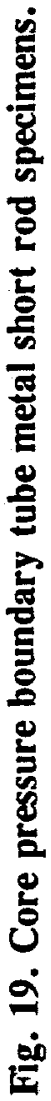




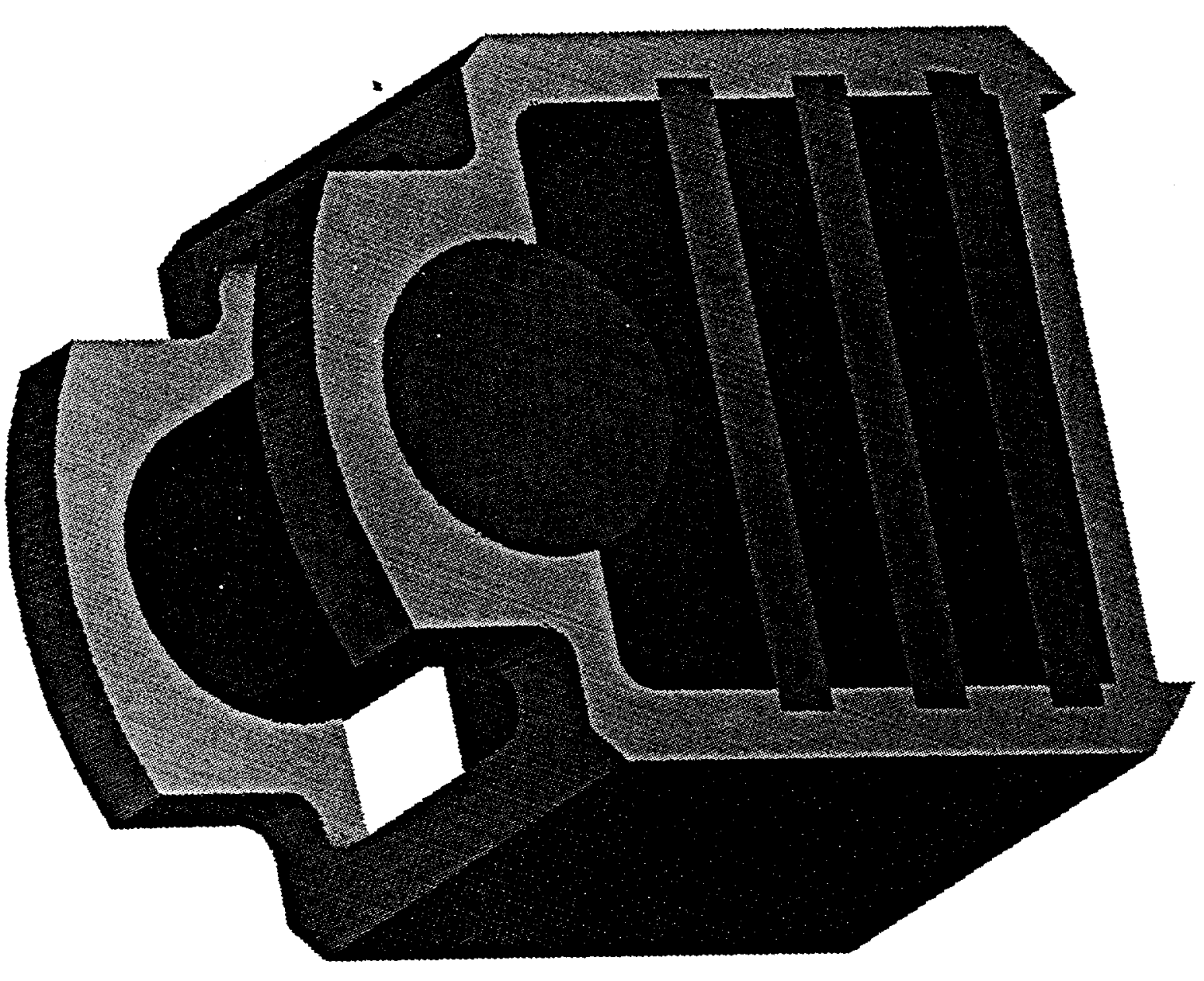

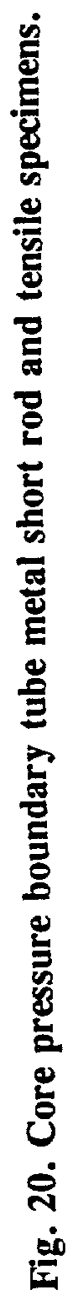


Table 2. Core pressure boundary tube and reflector vessel surveillance summary

\begin{tabular}{|c|c|c|c|c|c|c|}
\hline Metal & $\begin{array}{c}\text { Capsule } \\
\text { size }\end{array}$ & $\begin{array}{c}\text { Coupon } \\
\text { size }\end{array}$ & $\begin{array}{l}\text { Number of } \\
\text { capsules }\end{array}$ & $\begin{array}{c}\text { Number of } \\
\text { coupons per } \\
\text { capsule }\end{array}$ & $\begin{array}{c}\text { Testing } \\
\text { temp }\end{array}$ & $\begin{array}{l}\text { Capsule } \\
\text { location }\end{array}$ \\
\hline $\begin{array}{l}\text { CPBT } \\
\text { base } \\
\text { metal }\end{array}$ & $46 \mathrm{~mm}$ diam. & $\begin{array}{l}16 \mathrm{~mm} \text { diam. } \times \\
24 \mathrm{~mm} \text { height } \\
\text { short rod } \\
27.9 \times 11.4 \times \\
2.6 \mathrm{~mm} \text { tensile }\end{array}$ & 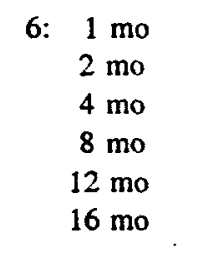 & $\begin{array}{l}6 \text { fracture } \\
\text { toughness } \\
3 \text { tensile }\end{array}$ & & Slant hole 1 \\
\hline $\begin{array}{l}\text { CPBT } \\
\text { weld } \\
\text { metal }\end{array}$ & & $\begin{array}{l}16 \mathrm{~mm} \text { diam. } \times \\
24 \mathrm{~mm} \text { height short rod } \\
27.9 \times 11.4 \times \\
2.6 \mathrm{~mm} \text { tensile }\end{array}$ & $\begin{array}{l}7: 1 \mathrm{mo} \\
2 \mathrm{mo} \\
4 \mathrm{mo} \\
8 \mathrm{mo} \\
12 \mathrm{mo} \\
16 \mathrm{mo} \\
\text { extra }\end{array}$ & & & \\
\hline $\begin{array}{l}\text { CPBT } \\
\text { HAZ } \\
\text { metal }\end{array}$ & & $\begin{array}{l}16 \mathrm{~mm} \text { diam. } \times \\
24 \mathrm{~mm} \text { height } \\
\text { short rod } \\
27.9 \times 11.4 \times \\
2.6 \mathrm{~mm} \text { tensile }\end{array}$ & 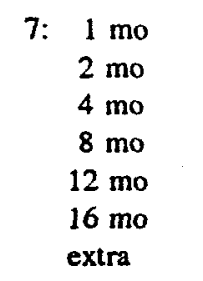 & & & \\
\hline $\begin{array}{l}\text { Reflector } \\
\text { vessel } \\
\text { base } \\
\text { metal }\end{array}$ & & $\begin{array}{l}16 \mathrm{~mm} \text { diam. } \times \\
24 \mathrm{~mm} \text { height } \\
\text { short rod } \\
27.9 \times 11.4 \times \\
2.6 \mathrm{~mm} \text { tensile }\end{array}$ & $\begin{array}{l}\text { 8: } 1.5 \text { years } \\
3 \text { years } \\
6 \text { years } \\
15 \text { years } \\
20 \text { years } \\
30 \text { years } \\
40 \text { years } \\
\text { extra }\end{array}$ & & & \\
\hline $\begin{array}{l}\text { Reflector } \\
\text { vessel } \\
\text { weld } \\
\text { metal }\end{array}$ & & $\begin{array}{l}16 \mathrm{~mm} \text { diam. } \times \\
24 \mathrm{~mm} \text { height } \\
\text { short rod } \\
27.9 \times 11.4 \times \\
2.6 \mathrm{~mm} \text { tensile }\end{array}$ & $\begin{array}{l}\text { 8: } 1.5 \text { years } \\
3 \text { years } \\
6 \text { years } \\
15 \text { years } \\
20 \text { years } \\
30 \text { years } \\
40 \text { years } \\
\text { extra }\end{array}$ & & & \\
\hline $\begin{array}{l}\text { Reflector } \\
\text { vessel } \\
\text { HAZ } \\
\text { metal }\end{array}$ & & $\begin{array}{l}16 \mathrm{~mm} \text { diam. } \times \\
24 \mathrm{~mm} \text { height } \\
\text { short rod } \\
27.9 \times 11.4 \times \\
2.6 \mathrm{~mm} \text { tensile }\end{array}$ & $\begin{array}{l}\text { 8: } 1.5 \text { years } \\
3 \text { years } \\
6 \text { years } \\
15 \text { years } \\
20 \text { years } \\
30 \text { years } \\
40 \text { years } \\
\text { extra }\end{array}$ & & & \\
\hline
\end{tabular}




\section{REFERENCES}

1. ASME Boiler and Pressure Vessel Code, Nuclear Code Case N-519, "Use of 6061-T6 and 6061-T651 Aluminum for Class 1 Nuclear Components, Section III, Division I," American Society of Mechanical Engineers, New York, Approval Date September 17, 1993.

2. "E185-82 Standard Practice for Conducting Surveillance Tests for Light-Water Cooled Nuclear Power Reactor Vessels," Annual Book of ASTM Standards, Vol. 03.01, Philadelphia, 1991.

3. D. J. Alexander, "The Effects of Irradiation on the Mechanical Properties of 6061-T651 Aluminum," pp. 1151-1167 in Proceedings of the 16th International Symposium on the Effects of Radiation on Materials, ASTM STP-1175, American Society of Testing and Materials, Philadelphia, 1994.

4. D. J. Alexander, "The Effects of Irradiation to $8 \times 10^{26} \mathrm{~m}^{-2}$ on the Mechanical Properties of 6061-T651 Aluminum," presented at the 17th International Symposium on the Effects of Radiation on Materials, Sun Valley, Idaho, June 23, 1994.

5. G. T. Yahr, Martin Marietta Energy Systems, Inc., memorandum to S. Heavilin, Martin Marietta Energy Systems, Inc., "Meeting on HANSAL-T3/T4 Irradiation Capsules," Oak Ridge, Tenn., July 15, 1994.

6. "E1304-89 Standard Test Method for Plane-Strain (Chevron-Notch) Fracture Toughness of Metallic Materials," Annual Book of ASTM Standards, Vol. 03.01, Philadelphia, 1994.

7. L. M. Barker, "Theory for Determining $K_{\mathrm{lc}}$ from Small, Non-LEFM Specimens, Supported by Experiments on Aluminum," International Journal of Fracture, 15 (6), 515-536 (December 1979).

8. "E399-90 Standard Test Method for Plane-Strain Fracture Toughness Testing of Metallic Materials," Annual Book of ASTM Standards, Vol. 03.01, Philadelphia, 1994.

9. C. A. Wemple, Detailed Flux Calculations for the Conceptual Design of the Advanced Neutron Source Reactor, Idaho National Engineering Laboratory, March 1994. 


\section{ATTACHMENT 1}

Code Case N-519: Use of 6061-T6 and 6061-T651 Aluminum for Class 1 Nuclear Components Section III, Division I 
Case N-519

Use of 6061-T6 and 6061-T651 Aluminum for Class 1 Nuclear Components, Section III, Division I

Inquiry:

Under what conditions may 6061-T6 and 6061-T651 aluminum be used in the construction of Section II, Division 1, Class 1 welded pressure vessels at temperatures not exceeding $300^{\circ} \mathrm{F}$ ?

Reply:

It is the opinion of the Committee that 6061-T6 and 6061-T651 aluminum may be used at temperatures not exceeding $300^{\circ} \mathrm{F}$ for the construction of Section III, Division 1, Class 1 welded vessels provided the following requirements are met:

1. Materials shall conform to the specifications listed in Table 1 for the various product forms. Chemical composition requirements of Table 2 shall be met.

2. Fabrication shall conform to the applicable requirements of Section III.

3. Design stress intensity values and specified minimum strength values given in Table 3 shall be used.

4. Yield strength values given in Table 4 and tensile strength values given in Table 5 shall be used.

5. The charts in Figs. NFA-12 and NFA-13 in Section II, Part D, Subpart 3 shall be used for external pressure design (NB-3133) at temperatures at/or below the maximum temperature for which design stress intensity values are listed in Table 3. Tabular values are given in Tables NFA-12 and NFA-13 in Section II, Part D, Subpart 3.

6. The fatigue design curves shown in Fig. 1 shall be used for fatigue evaluation. Tabular values are given in Table 6 . The allowable stress values, $S_{a}$, shall be reduced to one-half the values given in Fig. 1 and Table 6 within 1.0 inch of a weld.

7. Post weld heat-treatment is not permitted

8. When the Design Specification stipulates more than ten thousand cycles, the quantity used instead of $S_{y}$ for evaluating thermal ratcheting in the ratcheting rules of NB-3222.5(b) shall be $14 \mathrm{ksi}$ for base metal and $7 \mathrm{ksi}$ within 1.0 inch of a weld.

9. Simplified elastic-plastic analysis rules of NB-3228.5 are not applicable. The $3 \mathrm{~S}_{\mathrm{m}}$ limit on the range of primary plus secondary stress intensity (NB-3222.2) shall not be exceeded. 


\section{Attachment 1 (continued)}

10. Protection against non-ductile fracture shall be provided. The procedure for evaluating non-ductile fracture shall be the same as Appendix $G$ except that a value of $23 \mathrm{ksi}$ in shall be used for the critical, or reference, stress intensity factor, $K_{I R}(G-2110)$ for both base metal and welds.

11. This material is known to be susceptible to embrittlement as a result of neutron irradiation. When the component will be subjected to neutron irradiation during service, the Design Specification shall include requirements for consideration of the effects of neutron irradiation on the fracture toughness and requirements for replacement of components before they pose a hazard for brittle fracture. The designer shall establish the irradiated $K_{\mathbb{R}}$ value. That value shall be used to determine when components must be replaced. An in-service surveillance program similar to the one given in ASTM E185-82 for light-water cooled nuclear power reactor vessels shall be established to monitor the embrittlement of the reactor vessel material. If data from surveillance tests indicate that the established $K_{\mathbb{R}}$ value is unconservative, the component replacement schedule must be modified appropriately. The designer shall ensure that loss of ductility in-service does not invalidate the $3 \mathrm{~S}_{\mathrm{m}}$ limit on the range of primary plus secondary stress.

12. All other requirements of Section II, Division 1, for Class 1 construction, as applicable, shall be met.

13. This Code Case shall be identified on the Materials Manufacturer's certification for the material and on the applicable Data Report Form furnished by the $\mathrm{N}$-Type Certificate Holder.

14. The designer shall evaluate potential chemical reactions with the environment for both normal and design basis accident conditions and ensure that significant loss of strength or significant hydrogen generation will not occur.

\section{TABLE 1. SPECIFICATIONS}

SB-209

SB-210

SB-241/SB-241M

SB-221

SB-247
Sheet and Plate

Drawn Seamless Tube

Seamless Pipe and Seamless Extruded Tube

Extruded Bar, Rod, and Shape

Die and Hand Forgings 
TABLE 2. CHEMICAL COMPOSITION LIMITS $1,2,3$

\begin{tabular}{ll}
\hline \multicolumn{1}{c}{ Alloy 6061 } & Composition, \% \\
\hline Silicon & $0.40-0.80$ \\
Iron & 0.70 \\
Copper & $0.15-0.40$ \\
Manganese & 0.15 \\
Magnesium & $0.80-1.20$ \\
Chromium & $0.04-0.35$ \\
Zinc & 0.25 \\
Titanium & 0.15 \\
Other elements each & 0.05 \\
Other elements, total ${ }^{4}$ & 0.15 \\
Aluminum & remainder \\
\hline
\end{tabular}

1Where single units are shown, these indicate the maximum amounts permitted.

${ }^{2}$ Analysis shall regularly be made only for the elements specified in this table. If, however, the presence of other elements is suspected or indicated in the course of routine analysis, further analysis shall be made to determine that these elements are not in excess of the amount specified.

${ }^{3}$ For purposes of determining conformance to these limits, an observed value or a calculated value obtained from analysis shall be rounded to the nearest unit in the last right-hand place of figures used in expressing the specified limit, in accordance with the rounding method of Recommended Practice E 29.

${ }^{4}$ Other Elements-Total shall be the sum of unspecified metallic elements $0.010 \%$ or more, rounded to the second decimal before determining the sum. 


\section{Attachment 1 (continued)}

TABLE 3. DESIGN STRESS INTENSITY VALUES, $S_{m}$, FOR 6061-T6 AND 6061-T651 ALUMINUM

\begin{tabular}{|c|c|c|c|c|c|c|c|c|c|c|}
\hline \multirow{2}{*}{$\begin{array}{l}\text { Spec. } \\
\text { No. }\end{array}$} & \multirow[b]{2}{*}{ Temper } & \multirow{2}{*}{$\begin{array}{l}\text { Size or } \\
\text { thickness } \\
\text { (in) }\end{array}$} & \multirow{2}{*}{$\begin{array}{l}\text { Specified } \\
\text { Min. } \\
\text { Tensile } \\
\text { Strength } \\
\text { (ksi) }\end{array}$} & \multirow{2}{*}{$\begin{array}{l}\text { Specified } \\
\text { Min. Yield } \\
\text { Strength } \\
\text { (ksi) }\end{array}$} & \multirow[b]{2}{*}{ Notes } & \multicolumn{5}{|c|}{$\begin{array}{l}\text { Allowable Stress, ksi, for } \\
\text { Metal Temp, }{ }^{\circ} \text {. Nol Exceeding }\end{array}$} \\
\hline & & & & & & 100 & 150 & 200 & 250 & 300 \\
\hline \multicolumn{11}{|c|}{ Sheet and Plate } \\
\hline \multirow[t]{4}{*}{ SB-209 } & T6 & $\begin{array}{l}0.051- \\
0.249\end{array}$ & 42 & 35 & $(1)(2)$ & 14.0 & 14.0 & 14.0 & 13.4 & 11.3 \\
\hline & T651 & $\begin{array}{l}0.250 \\
4.000\end{array}$ & 42 & 35 & $(1)(2)$ & 14.0 & 14.0 & 14.0 & 13.4 & 11.3 \\
\hline & T651 & $\begin{array}{l}4.001 \\
6.000\end{array}$ & 40 & 35 & $(1)(2)$ & 13.3 & 13.3 & 13.3 & 13.0 & 11.1 \\
\hline & $\begin{array}{l}\text { T6,T651 } \\
\text { Wd }\end{array}$ & All & 24 & & (1) & 8.0 & 8.0 & 8.0 & 7.9 & 7.3 \\
\hline \multicolumn{11}{|c|}{ Rod, Bar, and Shape } \\
\hline \multirow[t]{2}{*}{ SB-221 } & T6 & All & 38 & 35 & $(1)(2)$ & 12.7 & 12.7 & 12.7 & 12.3 & 10.5 \\
\hline & T6 w/d. & All & 24 & & (1) & 8.0 & 8.0 & 8.0 & 7.9 & 7.3 \\
\hline \multicolumn{11}{|c|}{ Drawn Seamless Tube } \\
\hline \multirow[t]{2}{*}{ SB-210 } & T6 & $\begin{array}{l}0.025 \\
0.500\end{array}$ & 42 & 35 & $(1)(2)$ & 14.0 & 14.0 & 14.0 & 13.4 & 11.3 \\
\hline & T6 Wld. & All & 24 & & (1) & 8.0 & 8.0 & 8.0 & 7.9 & 7.3 \\
\hline \multicolumn{11}{|c|}{ Seamless Pipe } \\
\hline \multirow[t]{3}{*}{ SB-241 } & T6 & $<1$ & 42 & 35 & $(1)(2)$ & 14.0 & 14.0 & 14.0 & 13.4 & 11.3 \\
\hline & T6 & $\geq 1$ & 38 & 35 & $(1)(2)$ & 12.7 & 12.7 & 12.7 & 12.3 & 10.5 \\
\hline & T6 Wld. & All & 24 & & (1) & 8.0 & 8.0 & 8.0 & 7.9 & 7.3 \\
\hline \multicolumn{11}{|c|}{ Seamless Extruded Tube } \\
\hline \multirow[t]{2}{*}{ SB-241 } & T6 & All & 38 & 35 & $(1)(2)$ & 12.7 & 12.7 & 12.7 & 12.3 & 10.5 \\
\hline & T6 W/d. & All & 24 & & (1) & 8.0 & 8.0 & 8.0 & 7.9 & 7.3 \\
\hline \multicolumn{11}{|c|}{ Die and Hand Forgings } \\
\hline \multirow[t]{4}{*}{ SB-247 } & Die T6 & $\begin{array}{l}\text { Up thru } \\
4.000\end{array}$ & 38 & 35 & $(1)(2)$ & 12.7 & 12.7 & 12.7 & 12.1 & 10.5 \\
\hline & Hand T6 & $\begin{array}{l}\text { Up thru } \\
4.000\end{array}$ & 37 & 33 & $(1)(2)$ & 12.3 & 12.3 & 12.3 & 11.7 & 10.3 \\
\hline & Hand T6 & $\begin{array}{l}4.000 \\
8.000\end{array}$ & 35 & 32 & $(1)(2)$ & 11.7 & 11.7 & 11.7 & 11.2 & 9.9 \\
\hline & T6 Wld. & $\begin{array}{l}\text { Up thru } \\
8.000\end{array}$ & 24 & & (1) & 8.0 & 8.0 & 8.0 & 7.9 & 7.3 \\
\hline
\end{tabular}

Notes:

1. Design stress intensity values for $100^{\circ} \mathrm{F}$ may be used at temperatures down $t 0-452^{\circ} \mathrm{F}$ without additional specification requirements.

2. The stress values given for this material are not applicable when either welding or thermal cutting is employed. 
Attachment 1 (continued)

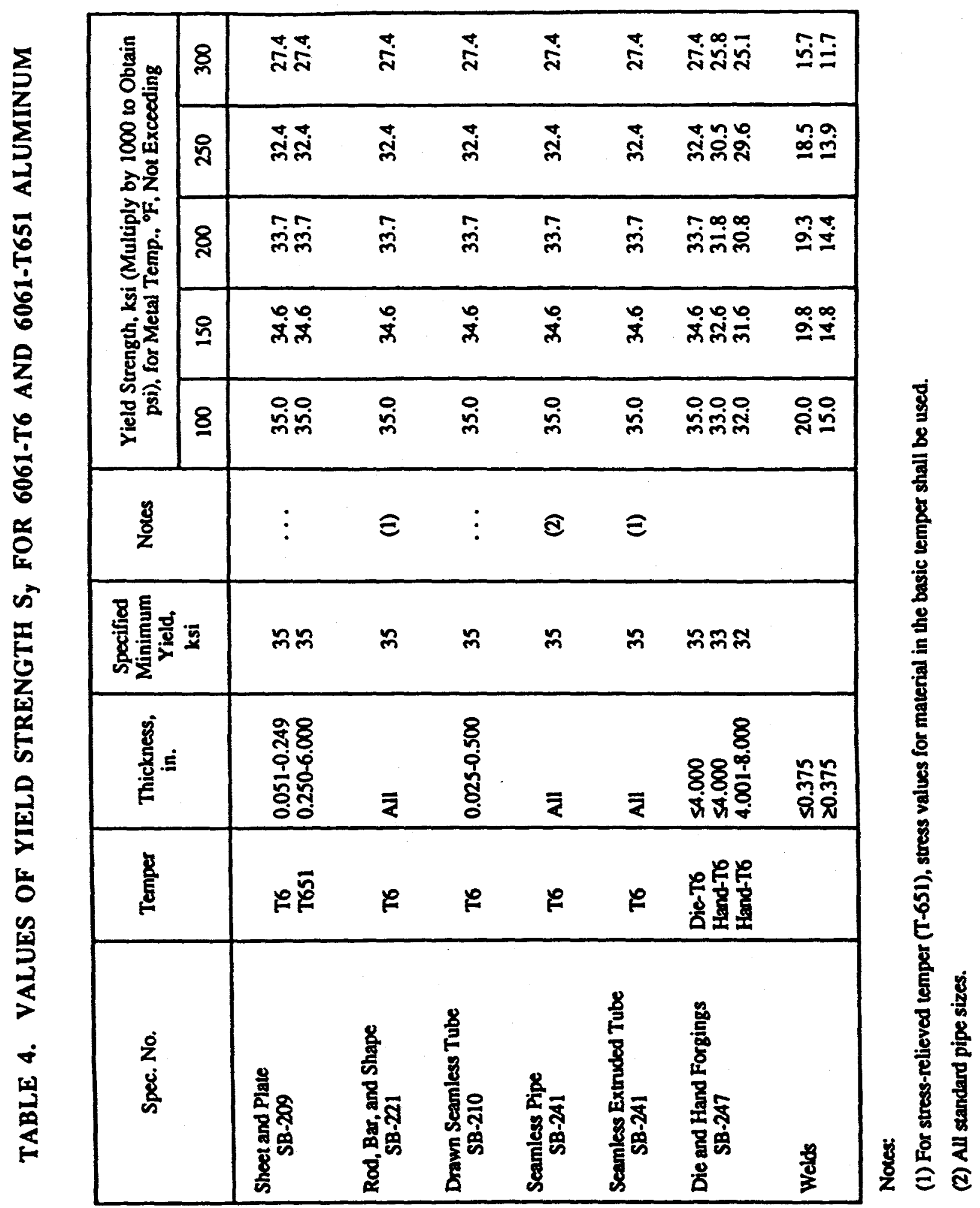


Attachment 1 (continued)

TABLE 5. TENSILE STRENGTH VALUES, $S_{u}$, FOR 6061-T6 AND 6061-T651 ALUMINUM

\begin{tabular}{|c|c|c|c|c|c|c|c|c|}
\hline \multirow{2}{*}{ Spec. No. } & \multirow[b]{2}{*}{ Temper } & \multirow{2}{*}{$\begin{array}{l}\text { Size or } \\
\text { thickness } \\
\text { (in) }\end{array}$} & \multirow{2}{*}{$\begin{array}{l}\text { Specified } \\
\text { Min. } \\
\text { Tensile } \\
\text { Strength } \\
\text { (ksi) }\end{array}$} & \multicolumn{5}{|c|}{$\begin{array}{c}\text { Tensile Strength, ksi, for } \\
\text { Metal Temo. }{ }^{\circ} \text { EN Nol Exceeding }\end{array}$} \\
\hline & & & & 100 & 150 & 200 & 250 & 300 \\
\hline \multicolumn{9}{|c|}{ Sheet and Plate } \\
\hline \multirow[t]{4}{*}{ SB-209 } & T6 & $\begin{array}{l}0.051- \\
0.249\end{array}$ & 42 & 42.0 & 42.0 & 42.0 & 40.2 & 33.9 \\
\hline & T651 & $\begin{array}{r}0.250 \\
4.000\end{array}$ & 42 & 42.0 & 42.0 & 42.0 & 40.2 & 33.9 \\
\hline & T651 & $\begin{array}{l}4.001- \\
6.000\end{array}$ & 40 & 40.0 & 40.0 & 40.0 & 39.0 & 33.3 \\
\hline & $\begin{array}{l}\text { T6,T651 } \\
\text { Whd. }\end{array}$ & All & 24 & 24.0 & 24.0 & 24.0 & 23.7 & 21.9 \\
\hline \multicolumn{9}{|c|}{ Rod, Bar, and Shape } \\
\hline \multirow[t]{2}{*}{ SB-221 } & T6 & All & 38 & 38.0 & 38.0 & 38.0 & 36.9 & 31.5 \\
\hline & T6 Wid. & All & 24 & 24.0 & 24.0 & 24.0 & 23.7 & 21.9 \\
\hline \multicolumn{9}{|c|}{ Drawn Seamless Tube } \\
\hline \multirow[t]{2}{*}{ SB-210 } & T6 & $\begin{array}{l}0.025 \\
0.500\end{array}$ & 42 & 42.0 & 42.0 & 42.0 & 40.2 & 33.9 \\
\hline & T6 Wld. & All & 24 & 24.0 & 24.0 & 24.0 & 23.7 & 21.9 \\
\hline \multicolumn{9}{|c|}{ Seamless Pipe } \\
\hline \multirow[t]{3}{*}{ SB-241 } & T6 & $<1$ & 42 & 42.0 & 42.0 & 42.0 & 40.2 & 33.9 \\
\hline & T6 & 21 & 38 & 38.0 & 38.0 & 38.0 & 36.9 & 31.5 \\
\hline & T6 Wid & All & 24 & 24.0 & 24.0 & 24.0 & 23.7 & 21.9 \\
\hline \multicolumn{9}{|c|}{ Seamless Extruded Tube } \\
\hline \multirow[t]{2}{*}{ SB-241 } & T6 & All & 38 & 38.0 & 38.0 & 38.0 & 36.3 & 31.5 \\
\hline & T6 W/d. & All & 24 & 24.0 & 24.0 & 24.0 & 23.7 & 21.9 \\
\hline \multicolumn{9}{|c|}{ Die and Hand Forgings } \\
\hline \multirow[t]{4}{*}{ SB.247 } & Die T6 & $\begin{array}{l}\text { Up thru } \\
4.000\end{array}$ & 38 & 38.0 & 38.0 & 38.0 & 36.3 & 31.5 \\
\hline & Hand T6 & $\begin{array}{l}\text { Up thru } \\
4.000\end{array}$ & 37 & 37.0 & 37.0 & 37.0 & 35.1 & 30.9 \\
\hline & Hand T6 & $\begin{array}{l}4.000 \\
8.000\end{array}$ & 35 & 35.0 & 35.0 & 35.0 & 33.6 & 29.7 \\
\hline & T6 w/d. & $\begin{array}{l}\text { Up thr } \\
8.000\end{array}$ & 24 & 24.0 & 24.0 & 24.0 & 23.7 & 21.9 \\
\hline
\end{tabular}


Attachment 1 (continued)

TABLE 6. TABULATED VALUES OF $S_{\mathrm{a}}$, ksi, FROM FIG. 1

$\begin{array}{ccc}\begin{array}{c}\text { Number of } \\ \text { Cycles } \\ \text { [Note (2)] }\end{array} & \begin{array}{c}\text { Zero } \\ \text { Mean }\end{array} & \begin{array}{c}\text { Maximum } \\ \text { Mean } \\ \text { Stress }\end{array} \\ \begin{array}{c}\text { Stress } \\ \text { 1.0E1 }\end{array} & 70.00 & 70.00 \\ 2.0 \mathrm{E} 1 & 70.00 & 70.00 \\ 5.0 \mathrm{E} 1 & 70.00 & 70.00 \\ 7.0 \mathrm{E} 1 & 70.00 & 70.00 \\ 1.0 \mathrm{E} 2 & 60.96 & 60.96 \\ 2.0 \mathrm{E} 2 & 47.20 & 47.20 \\ 5.0 \mathrm{E} 2 & 35.00 & 34.80 \\ 1.0 \mathrm{E} 3 & 28.85 & 26.79 \\ 2.0 \mathrm{E} 3 & 24.50 & 20.00 \\ 5.0 \mathrm{E} 3 & 20.64 & 13.78 \\ 7.0 \mathrm{E} 3 & 19.70 & 12.40 \\ 1.0 \mathrm{E} 4 & 17.50 & 10.93 \\ 2.0 \mathrm{E} 4 & 14.43 & 9.14 \\ 5.0 \mathrm{E} 4 & 11.70 & 7.74 \\ 9.0 \mathrm{E} 4 & 10.53 & 7.18 \\ 1.0 \mathrm{E} 5 & 10.32 & 6.89 \\ 2.0 \mathrm{E} 5 & 9.35 & 5.47 \\ 5.0 \mathrm{E} 5 & 8.49 & 4.36 \\ 1.0 \mathrm{E} 6 & 8.05 & 3.87 \\ 2.0 \mathrm{E} 6 & 7.74 & 3.55 \\ 5.0 \mathrm{E} 6 & 7.47 & 3.29 \\ 1.0 \mathrm{E} 7 & 7.33 & 3.16 \\ 2.0 \mathrm{E} 7 & 7.24 & 3.07 \\ 5.0 \mathrm{E} 7 & 7.15 & 3.00 \\ 1.0 \mathrm{E} 8 & 7.11 & 2.96 \\ 2.0 \mathrm{E} 8 & 7.07 & 2.93 \\ 5.0 \mathrm{E} 8 & 7.05 & 2.91 \\ 1.0 \mathrm{E} 9 & 7.03 & 2.90\end{array}$

Notes:

(1) Interpolation between tabular values is permissible based upon data representation by straight lines on a $\log$-log plot. See Table I-9.1, Note (2).

(2) The number of cycles indicated shall be read as follows: IEJ $=I \times 10^{\mathrm{J}}$, e.g., $5 \mathrm{EE} 6=5 \times 10^{6}$ or $5,000,000$ 
Attachment 1 (continued)

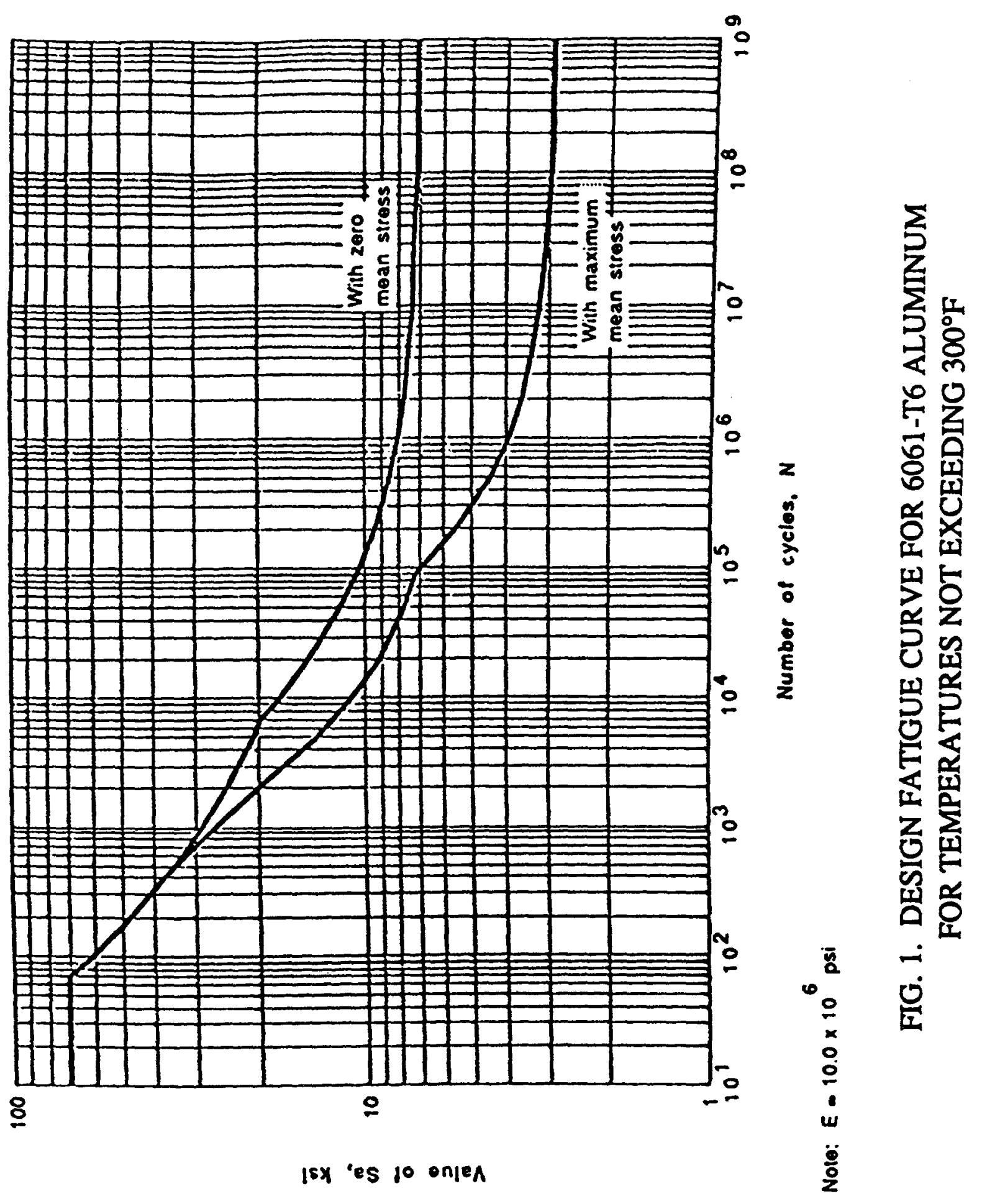


Internal Distribution

1. C. W. Alexander

2. D. J. Alexander

3. R. R. Allen

4. E. E. Alston

5. B. R. Appleton

6. R. E. Battle

7. R. S. Booth

8. W. W. Bowman

9. R. A. Brown

10. G. J. Bunick

11-15. J. H. Campbell

16. P. F. Cento

17. N. C. J. Chen

18. K. K. Chipley

19. J. E. Cleaves

20. J. T. Cleveland

21. G. L. Copeland

22. J. R. Dixon

23. K. Farrell

24. D. K. Felde

25. R. E. Fenstermaker

26. M. L. Gildner

27. H. A. Glovier

28. D. C. Haberkost

29. R. M. Harrington

30. J. B. Hayter

31. M. P. Hechler

32. W. E. Hill

33. S. E. Holliman

34. M. M. Houser

35. R. O. Hussung

36. D. T. Ingersoll

37-40. R. L. Johnson

41. J. R. Joplin

42. R. M. Leitch

43. R. A. Lillie

44. M. A. Linn

45. A. T. Lucas

46. J. A. March-Leuba

47. G. T. Mays

48. S. V. McGrath
49. T. J. McManamy

50. G. R. McNutt

51. J. T. Mihalczo

52. R. M. Moon

53. D. G. Morris

54. D. L. Moses

55. J. A. Novak

56. L. C. Oakes

57. R. E. Pawel

58. F. J. Peretz

59. G. M. Powers

60. C. C. Queen

61. S. Raman

62. C. T. Ramsey

63. J. S. Rayside

64. J. P. Renier

65. J. B. Roberto

66. L. R. Robinson

67. R. B. Rothrock

68. T. L. Ryan

69. J. P. Schubert

70. D. L. Selby

71. H. B. Shapira

72. M. Siman-Tov

73. R. P. Taleyarkhan

74. D. W. Theisen

75. K. R. Thoms

76. S. R. Tompkins

77. B. D. Warnick

78. M. W. Wendel

79. C. D. West

80. J. L. Westbrook

81. D. M. Williams

82. B. A. Worley

83. G. T. Yahr

84. G. L. Yoder

85. ORNL Patent Office

86. Document Research Library (2)

87. Y-12 Technical Library

88. Laboratory Records (2)

89. Laboratory Records (RC) 


\section{External Distribution}

90. R. Awan, U.S. Department of Energy, NE-473, Washington, DC 20585.

91. Mr. and Mrs. Robert Bailey,

92. F. Y. Chen, U.S. Department of Energy, Office of Nuclear Safety Performance Assessment, EH-11, CXXI/3, Washington, DC 20585.

93. Professor F. Clickeman, Nuclear Engineering Building, Purdue University, West Lafayette, IN 47906.

94. K. K. Conway, Laboratory Facilities Branch, U.S. Department of Energy, Oak Ridge Operations Office, CE-523, P.O. Box 2001, Oak Ridge, TN 37831-2001.

95. R. R. Fullwood, Brookhaven National Laboratory, Upton, NY 11973.

96. W. R. Gambill,

97. Mr. and Mrs. Robert Heavitin,

98. Susan M. Heavilin,

99. A. F. Henry, Professor, Department of Nuclear Engineering, Massachusetts Institute of Technology, 77 Massachusetts Avenue, Cambridge, MA 02139.

100. R. A. Hunter, Director, Office of Facilities, Fuel Cycle, and Test Programs, Nuclear Energy Division, U.S. Department of Energy, NE-47, Washington, DC 20585.

101. T. L. Kerlin, University of Tennessee, College of Engineering, 315 Pasqua Engineering Building, Knoxville, TN 37996-2300.

102. Kathy Ketner, Science/Engineering Education Office, Oak Ridge Institute for Science and Education, P.O. Box 117, Oak Ridge, TN 37831-0117.

103. J. A. Lake, Manager, Nuclear Engineering and Reactor Design, Idaho National Engineering Laboratory, P.O. Box 1625, Idaho Falls, ID 83415.

104. J. E. Mays, Research and Test Reactor Fuel Elements, Babcock and Wilcox Co., P.O. Box 785, Lynchburg, VA 24505.

105. J. P. Mulkey, U.S. Department of Energy, NE-473, Washington, DC 20585.

106. W. T. Oosterhuis, Materials Sciences Division, Office of Basic Energy Sciences, Office of Energy Research, U.S. Department of Energy, ER-132, Washington, DC 20585.

107. H. R. Payne,

108. J. M. Ryskamp, Idaho National Engineering Laboratory. P.O. Box 1625, Idaho Falls, ID 83415-3885.

109. J. L. Snelgrove, Coordinator, Engineering Applications, RERTR Program, Argonne National Laboratory, 9700 South Cass Avenue, Argonne, II 60439.

110. I. Thomas, Director, Materials Science Division, Office of Energy Research, U.S. Department of Energy, ER-13, Washington, DC 20585.

111. U.S. Department of Energy, ANS Project Office, Oak Ridge Operations Office, FEDC, MS8218, P.O. Box 2009, Oak Ridge, TN 37831-8218.

112. H. G. Wood, III, Associate Professor, Department of Mechanical and Aerospace Engineering, Thornton Hall, University of Virginia, Chariottesville, VA 22901.

113. Office of Assistant Manager for Energy Research and Development, U.S. Department of Energy, Oak Ridge Operations Office, P.O. Box 2001, Oak Ridge, TN 37831-2001.

114-115. Office of Scientific and Technical Information, P.O. Box 62, Oak Ridge, TN 37831. 